\title{
QUEEN'S
UNIVERSITY
BELFAST
}

\section{Water-in-CO2 microemulsions stabilized by fluorinated cation-anion surfactant pairs}

Sagisaka, M., Saito, T., Yoshizawa, A., Rogers, S. E., Guittard, F., Hill, C., Eastoe, J., \& Blesic, M. (2019). Water-in-CO2 microemulsions stabilized by fluorinated cation-anion surfactant pairs. Langmuir, 35(9), 3445. https://doi.org/10.1021/acs.langmuir.8b03942

\section{Published in:}

Langmuir

\section{Document Version:}

Peer reviewed version

Queen's University Belfast - Research Portal:

Link to publication record in Queen's University Belfast Research Portal

\section{Publisher rights}

(c) 2019 American Chemical Society. This work is made available online in accordance with the publisher's policies. Please refer to any applicable terms of use of the publisher.

\section{General rights}

Copyright for the publications made accessible via the Queen's University Belfast Research Portal is retained by the author(s) and / or other copyright owners and it is a condition of accessing these publications that users recognise and abide by the legal requirements associated with these rights.

Take down policy

The Research Portal is Queen's institutional repository that provides access to Queen's research output. Every effort has been made to ensure that content in the Research Portal does not infringe any person's rights, or applicable UK laws. If you discover content in the Research Portal that you believe breaches copyright or violates any law, please contact openaccess@qub.ac.uk. 
Subscriber access provided by QUEENS UNIV BELFAST

\section{Interface Components: Nanoparticles, Colloids, Emulsions, Surfactants, Proteins, Polymers}

\section{Water-in-CO2 microemulsions stabilized by fluorinated cation-anion surfactant pairs}

Masanobu Sagisaka, Tatsuya Saito, Atsushi Yoshizawa, Sarah E. Rogers,

Frederic Guittard, Christopher Hill, Julian Eastoe, and Marijana Blesic

Langmuir, Just Accepted Manuscript • DOI: 10.1021/acs.langmuir.8b03942 • Publication Date (Web): 11 Feb 2019

Downloaded from http://pubs.acs.org on February 11, 2019

\section{Just Accepted}

"Just Accepted" manuscripts have been peer-reviewed and accepted for publication. They are posted online prior to technical editing, formatting for publication and author proofing. The American Chemical Society provides "Just Accepted" as a service to the research community to expedite the dissemination of scientific material as soon as possible after acceptance. "Just Accepted" manuscripts appear in full in PDF format accompanied by an HTML abstract. "Just Accepted" manuscripts have been fully peer reviewed, but should not be considered the official version of record. They are citable by the Digital Object Identifier (DOI®). "Just Accepted" is an optional service offered to authors. Therefore, the "Just Accepted" Web site may not include all articles that will be published in the journal. After a manuscript is technically edited and formatted, it will be removed from the "Just Accepted" Web site and published as an ASAP article. Note that technical editing may introduce minor changes to the manuscript text and/or graphics which could affect content, and all legal disclaimers and ethical guidelines that apply to the journal pertain. ACS cannot be held responsible for errors or consequences arising from the use of information contained in these "Just Accepted" manuscripts. 


\title{
Water-in- $\mathrm{CO}_{2}$ microemulsions stabilized by fluorinated cation-anion surfactant pairs
}

\author{
Masanobu Sagisaka ${ }^{1 *}$, Tatsuya Saito ${ }^{1}$, Atsushi Yoshizawa ${ }^{1}$, Sarah E. Rogers ${ }^{2}$, Frédéric Guittard ${ }^{3}$, \\ Christopher Hill4, Julian Eastoe ${ }^{4}$, Marijana Blesic ${ }^{5}$ \\ ${ }^{1}$ Department of Frontier Materials Chemistry, Graduate School of Science and Technology, Hirosaki \\ University, \\ 3 Bunkyo-cho, Hirosaki, Aomori 036-8561, JAPAN \\ ${ }^{2}$ ISIS-CCLRC, Rutherford Appleton Laboratory, Chilton, Oxon OX11 0QX, U.K. \\ ${ }^{3}$ Univ. Cote d'Azur, NICE-Lab, 61-63 av. S. Viel, 06200 Nice, France \\ ${ }^{4}$ School of Chemistry, University of Bristol, Cantock's Close, Bristol BS8 1TS, U.K. \\ ${ }^{5}$ School of Chemistry and Chemical Engineering, Queen's University Belfast, University Road, Belfast, \\ BT7 1NN, U.K. \\ *To whom all correspondence should be addressed \\ Masanobu SAGISAKA E-mail: sagisaka@hirosaki-u.ac.jp Phone and Fax:+81-172-39-3579
}




\begin{abstract}
High water-content water-in-supercritical $\mathrm{CO}_{2}\left(\mathrm{~W} / \mathrm{CO}_{2}\right)$ microemulsions are considered to be green, universal solvents, having both polar and nonpolar domains. Unfortunately, these systems generally require environmentally-unacceptable stabilizers like long and/or multi fluorocarbon-tail surfactants. Here, a series of catanionic surfactants having environmentally-friendly fluorinated $\mathrm{C}_{4}-\mathrm{C}_{6^{-}}$ tails have been studied in terms of interfacial properties, aggregation behavior and solubilizing power in water and/or $\mathrm{CO}_{2}$. The lowest surface tension and the critical micelle concentration of these catanionic surfactants are respectively lower by $\sim 9 \mathrm{mN} / \mathrm{m}$ and 100 times than the constituent single FC-tail surfactants. Disk-like micelles in water were observed above the respective critical micelle concentrations, implying the catanionic surfactants to have a high critical packing parameter (CPP), which should also be suitable to form reverse micelles. Based on visual observation of phase behavior, FT-IR spectroscopic and small-angle neutron scattering (SANS) studies, one of the three catanionic surfactants tested was found to form transparent single-phase $\mathrm{W} / \mathrm{CO}_{2}$ microemulsions with a water-to-surfactant molar ratio up to $\sim 50$. This is the first successful demonstration of the formation of $\mathrm{W} / \mathrm{CO}_{2}$ microemulsion by synergistic ion-pairing of anionic and cationic single-tail surfactants. It indicates that catanionic surfactants offer a promising approach to generate high water-content $\mathrm{W} / \mathrm{CO}_{2}$ microemulsions.
\end{abstract}

Keywords: Supercritical $\mathrm{CO}_{2}$, Microemulsion, catanionic surfactant, Solubilizing power, Small-Angle Neutron Scattering 


\section{Introduction}

Above its critical point $\left(31.1^{\circ} \mathrm{C}\right.$ and 73.8 bar $)$ supercritical fluid $\mathrm{CO}_{2}\left(\mathrm{scCO}_{2}\right)$ has multifarious practical applications for replacing volatile organic compounds (VOCs) and freons ${ }^{1}$. Furthermore, $\mathrm{scCO}_{2}$ has other attractive properties for industrial applications like inexpensiveness, inflammability, natural abundance, high mass transfer, and $\mathrm{CO}_{2}$ density-tunable solvency ${ }^{1}$. On the other hand, recovery of $\mathrm{CO}_{2}$ from power plants and utilizing it as a green solvent in chemical industries has some potential to abate the greenhouse effect. In fact, the green solvent $\mathrm{scCO}_{2}$ is currently employed for organic reactions, dry cleaning, polymerization, extraction, nanomaterial processing amongst others ${ }^{1}$. Unfortunately, $\mathrm{scCO}_{2}$ can realistically dissolve only nonpolar and low molecular weight (MW) compounds, and more often than not polar and/or high MW solutes are incompatible with $\mathrm{scCO}_{2}^{2}$. Hence, enhancing the poor solubility of polar and/or high-MW compounds is a key target for developing potential applications of $\mathrm{scCO}_{2}$. One of the most useful approaches to increase the solubility is to form molecular assemblies having hydrocarbon cores or polar cores able to solubilize those $\mathrm{CO}_{2}$-insoluble materials. In the latter case, it would be reverse micelles with aqueous or ionic liquid (IL) nanodroplets in the $\mathrm{scCO}_{2}$ phase, these are water-in-scCO microemulsions $\left(\mathrm{W} / \mathrm{CO}_{2} \mu \mathrm{Es}\right)$ or IL-in- $\mathrm{scCO}_{2} \mu$ Es. ${ }^{2,3}$ Since such thermodynamically-stable nanodispersions exhibit the advantageous characteristics of $\mathrm{scCO}_{2}$, as well as the solvation properties of bulk water and ILs, they have potential as volatile organic compound (VOC)-free and energy-efficient solvents for nano-material synthesis, enzymatic reactions, dry-cleaning, dyeing, and enhanced oil recovery, inorganic/organic nanocomposites production ${ }^{2,3}$, amongst other applications.

In order to be considered a green and economical technology, the level of surfactants present for stabilizing $\mu$ Es should be decreased as far as possible, and this needs to be balanced against that required for appropriate levels of dispersed water and/or interfacial areas in $\mu$ Es for individual applications. One approach to satisfy these requirements is to develop super-efficient surfactant stabilizers and solubilizers for the $\mu$ Es. The water-to-surfactant molar ratio $W_{0}(=[$ water $] /[$ surfactant $])$ is an important indicator for evaluating the solubilizing efficiency, namely, the highest $W_{0}$ attainable in a single-phase $\mathrm{W} / \mathrm{CO}_{2} \mu \mathrm{E}$ $\left(W_{0}{ }^{\max }\right)$ can be called the water-solubilizing power of the surfactant. (As such $W_{0}{ }^{\max }$ represents the 
maximum number of water molecules which can be solubilized by one surfactant molecule). The studies aiming to find efficient $\mathrm{CO}_{2}$-philic solubilizers started in the $1990 \mathrm{~s}^{4}$ and continue nowadays ${ }^{5-15}$.

Therefore, exploring $\mathrm{CO}_{2}$-philic hydrocarbon $(\mathrm{HC})$ surfactants for $\mathrm{scCO}_{2}$ remains an important task. ${ }^{4-7}$ However, most commercial and popular $\mathrm{HC}$ surfactants are insoluble and unusable in the $\mathrm{scCO}_{2}$ solvent medium. ${ }^{4}$ For example, although the common HC-surfactant Aerosol-OT (sodium bis-(2-ethyl-1hexyl) sulfosuccinate, AOT, Figure $\mathbf{S 1}$ in supporting information) is well-known to exhibit very high $W_{0}{ }^{\max }$ values in water-in-oil $\mu$ Es (e.g. $W_{0}{ }^{\max }=\sim 80$ in $n$-heptane at $25^{\circ} \mathrm{C}$ ) ${ }^{8}, W_{0}{ }^{\max }$ was found to be zero in dense $\mathrm{scCO}_{2} \cdot{ }^{9}$ It has been realized that conventional surfactant-design theory is inapplicable to $\mathrm{W} / \mathrm{CO}_{2}$ systems, and that $\mathrm{CO}_{2}$-philicity is not directly comparable to oleo-philicity. Therefore, molecular-design theory for $\mathrm{CO}_{2}$-philic surfactants has to be advanced with new directions and paradigms in the field of surfactant chemistry. In looking for $\mathrm{CO}_{2}$-soluble compounds, highly branched $\mathrm{HCs}{ }^{4-7}$, especially with methyl-branches and ester groups have been found to exhibit high solubility in $\mathrm{scCO}_{2}$. However, an efficient and cost-effective $\mathrm{HC}$ solubilizer for $\mathrm{W} / \mathrm{CO}_{2} \mu \mathrm{Es}$, like the AOT utilized widely for $\mathrm{W} / \mathrm{O} \mu \mathrm{Es}^{4-9}$ has not yet been developed.

In contrast with the poor solubilizing power of $\mathrm{HC}$ surfactants, some anionic fluorinated surfactants having perfluoropolyether (PFPE), double fluorocarbon (FC) and FC-HC hybrid tailstructures were reported to be highly soluble in $\mathrm{CO}_{2}$ and surface-active at the $\mathrm{W} / \mathrm{CO}_{2}$ interface, promising formation of $\mathrm{W} / \mathrm{CO}_{2} \mu$ Es. ${ }^{9-15}$ In the cases of the PFPE surfactant $\left(\mathrm{PFPECOONH}_{4}\right)$, the hybrid surfactant FC6-HC4 and the double perfluorooctyl tail surfactant $8 \mathrm{FG}(\mathrm{EO})_{2}$ (Figure $\mathrm{S} 1$ in supporting information), the $W_{0}{ }^{\text {max }}$ values were found to be $\sim 20, \sim 80$ and $\sim 60$, respectively. ${ }^{9,14,15}$

Along with the efforts to explore and develop $\mathrm{CO}_{2}$-philic surfactants, applied research into using $\mathrm{W} / \mathrm{CO}_{2} \mu$ Es has also been conducted for nanoparticle (NP) synthesis ${ }^{16}$, enzymatic reactions ${ }^{17}$, dry cleaning ${ }^{18}$, and extraction ${ }^{19}$. However, in these applications, employing ionic surfactants often leads to disadvantages. For example, in NP synthesis ${ }^{16}$ of $\mathrm{ZnS}, \mathrm{CdS}$, and $\mathrm{TiO}_{2}$ using $\mathrm{W} / \mathrm{CO}_{2} \mu \mathrm{Es}$, the anionic $\mathrm{FC}$ surfactant $8 \mathrm{FG}(\mathrm{EO})_{2}$ strongly binds to the NPs via (electrostatic) attractive interactions between the headgroups and charged NP surfaces. Therefore, the NP products collected after removing $\mathrm{CO}_{2}$ usually 
include surfactant residues, requiring further purification and removal processes. Since these extra processes require the use of additional solvents, overall the processes cannot be identified as truly environmentally friendly. For extraction and dry cleaning using $\mu$ Es, washings and extracts are also suspected to have surfactant residue in the same manner as for NP production. For enzymatic reactions in $\mathrm{W} / \mathrm{CO}_{2} \mu \mathrm{Es}$, enzymes are known to be deactivated/denatured by ionic surfactants ${ }^{20}$. These problems will always crop up in applications using ionic surfactant-stabilized $\mu$ Es. Keeping these limitations in mind, an efficient and cost-effective $\mathrm{CO}_{2}$-philic surfactant for practical applications could be tailored to contain nonionic and small headgroups (i.e. not a conventional poly(ethylene oxide) (PEO) group with a high $\mathrm{MW}$ ) that are $\mathrm{CO}_{2}$-philic, whilst being less polar and therefore less likely to bind unfavorably to other materials.

On the other hand, there are some reports of low-polarity compounds for solubilizing ionic substances in liquid or supercritical $\mathrm{CO}_{2}$ phase ${ }^{3,21}$. For example, DeSimone et al. ${ }^{21}$ demonstrated that dendrimers having FC shells dissolved in liquid $\mathrm{CO}_{2}$ and solubilized an ionic dye methyl orange in the dendrimer cores. Liu et $a l .{ }^{3}$ reported that the fluorinated compound N-ethylperfluorooctylsulfonamide generated $\mathrm{IL} / \mathrm{CO}_{2} \mu \mathrm{Es}$ with three ILs of 1,1,3,3-tetramethylguanidinium acetate, lactate and trifluoroacetate, and that these $\mu$ Es solubilized ionic compounds like methyl orange, $\mathrm{CoCl}_{2}$ and $\mathrm{HAuCl}_{4}$. These findings show that additives with non-traditional surfactant architectures can potentially play the roles of polar solubilizers and microemulsifiers in $\mathrm{scCO}_{2}$. Recently, a FC-HC compound without a headgroup (Nohead FC6-HCn, Figure S1 in supporting information) as an analogue of the superefficient surfactant FC6-HCn was found to stabilize $\mathrm{W} / \mathrm{CO}_{2} \mu \mathrm{Es}^{22}$ Even that Nohead FC6-HC4 is not formally recognized as a traditional surfactant (no identifiable head group), $\mathrm{W} / \mathrm{CO}_{2} \mu$ Es were formed even under a mild pressure and temperature conditions (approaching the critical point of $\mathrm{CO}_{2}$ ), whereas similar analogues with different HC-tail lengths did not form $\mu$ Es. Those nonionic solubilizers introduced above are likely to adhere to target materials in the applications of $\mathrm{W} / \mathrm{CO}_{2} \mu$ Es. Unfortunately, these solubilizers were inefficient $\left(W_{0} \max <10\right)$, expensive, and therefore not really much use for applications with high water-content $\mathrm{W} / \mathrm{CO}_{2} \mu \mathrm{Es}$. 
One of the effective ways to enhance surfactant performance is through ion-pairing of cationic and anionic surfactants, that is formation of catanionic surfactants. Compared with the parent surfactant ions, catanionic surfactants exhibit many useful and novel properties in water and/or oil like enhanced surface activity and adsorption and much lower critical aggregation concentrations, a cloud temperature phenomenon, and formation of vesicles (or reverse vesicles) and shape-anisotropic micelles (or shapeanisotropic reverse micelles). ${ }^{23-30}$ These unique, or improved, surfactant properties mainly come from an increased critical packing parameter (CPP) $)^{31,32}$ and a decreased hydrophilic-lipophilic balance (HLB) ${ }^{33-35}$ based on the strong electrostatic interactions between anionic and cationic headgroups ${ }^{23-30}$. With increasing CPP and decreasing HLB reverse micelles become more stable ${ }^{31-35}$, hence catanionic surfactants could be advantageous for stabilizing reverse micelles and $\mathrm{W} / \mathrm{CO}_{2} \mu \mathrm{Es}$.

Another advantage of catanionic surfactants is the nonionic surfactant-like feature (e.g. cloud temperature not Krafft temperature for an ionic surfactant) even though they formally bear ionic groups. ${ }^{24}$ For example, the reverse micelles in ternary system of the catanionic surfactant octylammoniumoctanoate, octane and water were reported to grow uniaxially as $W_{0}$ and surfactant concentration increased or the temperature decreased..$^{30}$ The variation of spontaneous curvature with temperature seen to be the same as for other nonionic surfactants. Ion-pairing of the parent surfactant anion and cation probably affects the charge of the $\mathrm{W} / \mathrm{O} \mu \mathrm{E}$ interface, and hence has an effect on the spontaneous curvature/structure. ${ }^{30}$ For this reason catanionic surfactants may interact more weakly with target materials and overcome the issues of strong surface binding and complexation encountered with formal ionic surfactants. Some earlier studies $^{36-40}$ also tested inorganic and enzymatic reactions in catanionic surfactant reverse micelles and yielded inorganic nanomaterials with unique shapes (e.g. nanowires and nanobelts) and a high enzymatic activity compared with in those of the parent cationic surfactants. Till now catanionic surfactants have not been investigated for stabilizing $\mathrm{W} / \mathrm{CO}_{2} \mu \mathrm{Es}$.

This study has evaluated three different catanionic surfactants to examine efficiency and effectiveness of surfactant structure and the synergistic effects of ion-pairing for the formation of $\mathrm{W} / \mathrm{CO}_{2}$ $\mu$ Es. These catanionic surfactants (Table 1) have environmentally-acceptable $\mathrm{C}_{4}-\mathrm{C}_{6} \mathrm{FC}$ tails and have 
been investigated in terms of surface tension lowering and micelle formation in water, water solubilizing power in $\mathrm{scCO}_{2}$ and properties of the $\mu \mathrm{E}$ droplets. The results help identify important design criteria for inexpensive and environmental-friendly catanionic surfactants to stabilize $\mathrm{W} / \mathrm{CO}_{2} \mu$ Es as green and universal solvents for potential applications.

\section{Experimental Section}

\section{Materials}

The catanionic surfactants used in this study were surfactant cation-anion pairs of $\left[\mathrm{C}_{6} \mathrm{~F}_{13} \mathrm{mim}\right]\left[\left(\mathrm{CF}_{3}\right)_{3} \mathrm{~S}\right],\left[\mathrm{C}_{6} \mathrm{~F}_{13} \mathrm{mim}\right]\left[\mathrm{C}_{6} \mathrm{~F}_{13} \mathrm{~S}\right]$ and $\left[\mathrm{C}_{5} \mathrm{~F}_{11} \mathrm{mim}\right]\left[\mathrm{C}_{5} \mathrm{~F}_{11} \mathrm{~S}\right]$ (Table 1), respectively. The synthesis and purification of surfactants $\left[\mathrm{C}_{6} \mathrm{~F}_{13} \mathrm{mim}\right]\left[\mathrm{C}_{6} \mathrm{~F}_{13} \mathrm{~S}\right]$ and $\left[\mathrm{C}_{5} \mathrm{~F}_{11} \mathrm{mim}\right]\left[\mathrm{C}_{5} \mathrm{~F}_{11} \mathrm{~S}\right]$ were reported in a previous study. ${ }^{35}\left[\mathrm{C}_{6} \mathrm{~F}_{13} \mathrm{mim}\right]\left[\left(\mathrm{CF}_{3}\right)_{3} \mathrm{~S}\right]$ was newly synthesized as described in supporting information (Scheme S1). The individual single FC-tail surfactants with $\mathrm{Na}^{+}$or $\mathrm{CH}_{3} \mathrm{SO}_{3}{ }^{-}$(MeS: methyl sulfonate) counterions, namely $\mathrm{Na}\left[\mathrm{C}_{6} \mathrm{~F}_{13} \mathrm{~S}\right], \mathrm{Na}\left[\left(\mathrm{CF}_{3}\right)_{3} \mathrm{~S}\right]$ and $\mathrm{MeS}\left[\mathrm{C}_{6} \mathrm{~F}_{13} \mathrm{mim}\right]$ were also employed as a control.

Ultrapure water with a resistivity of $18.2 \mathrm{M} \Omega \mathrm{cm}$ was produced by a Millipore Milli-Q Plus system. $\mathrm{CO}_{2}$ of $99.99 \%$ purity was purchased from Ekika Carbon Dioxide Co., Ltd. The structures of the steric models and the lengths of surfactants were estimated by MM2 (Molecular Mechanics program 2) calculations (Chem 3D; CambridgeSoft Corp., Cambridge, MA).

\section{Phase behavior observation and FT-IR spectral measurements for surfactant/scC $\mathrm{CO}_{2}$ mixtures}

A high-pressure (HP) cell with a metal-to-glass sealed glass window (KP-308-3, Nihon Klingage co., ltd) and a moveable piston inside the cell was employed to examine phase behaviour of surfactant $/$ water $/ \mathrm{scCO}_{2}$ mixtures by operating pressure and temperature. A detailed description of the experimental apparatus and procedures was introduced in earlier papers. $.^{9} 14-16$

Formation of $\mathrm{W} / \mathrm{CO}_{2} \mu$ Es was investigated by FT-IR spectroscopy with a pressure cell (volume: $1.5 \mathrm{~cm}^{3}$ ), connected to the HP-apparatus mentioned above. The FT-IR spectra were measured with a FTIR spectrometer (JASCO Co., FT/IR-4700). The cells were made of stainless steel (SUS316) and had 
three zinc sulfide windows (thickness: $8 \mathrm{~mm}$, inner diameter: $10 \mathrm{~mm}$ ). Each window was positioned to provide a perpendicular $10-\mathrm{mm}$ optical path. The windows were attached and fastened tightly to the stainless-steel body of the cell with PTFE kel-F packings, thereby compressing the packings between the stainless steel parts and the windows and providing efficient sealing (tested up to 400 bar). The cell temperature was controlled by circulating water with a thermostat bath.

Visual observation of the water/surfactant $/ \mathrm{scCO}_{2}$ systems was carried out at temperatures of 35 $75^{\circ} \mathrm{C}$ and pressures $<400$ bar. The densities of $\mathrm{CO}_{2}$ were estimated using the Span-Wagner equation of state (EOS) ${ }^{41}$. Pre-determined amounts of surfactant and $\mathrm{CO}_{2}(20.0 \mathrm{~g})$, where the molar ratio of surfactant to $\mathrm{CO}_{2}$ was fixed at $8 \times 10^{-4}$, were loaded into the variable-volume HP-cell. Then, water was loaded into the cell through a six-port valve with a $20 \mu \mathrm{L}$ sample loop until the clear Winsor-IV $\mathrm{W} / \mathrm{CO}_{2} \mu \mathrm{E}$ (i.e. single-phase $\mathrm{W} / \mathrm{CO}_{2} \mu \mathrm{E}$ ) solution became a turbid macroemulsion or a precipitated hydrated surfactant. Surfactant molar concentration was in the range $10-20 \mathrm{mM}$, for example $16.7 \mathrm{mM}$ at $45^{\circ} \mathrm{C}$ and 350 bar, as the inner volume of the cell was varied by changing experimental pressure and temperature.

During the spectroscopic measurements, the $\mathrm{scCO}_{2}$ mixture was stirred and circulated between the optical vessel and the window cell until a constant absorbance was attained. The circulation was then discontinued; the valves between the vessel and the window cell were closed, and the FT-IR spectrum was measured. The physical properties of the continuous phase of $\mathrm{scCO}_{2}$ were assumed to be equivalent to those of pure $\mathrm{CO}_{2}$.

\section{High-Pressure and ambient pressure small-angle neutron scattering (SANS) measurements and data analysis}

Due to the range of neutron wavelengths available, time-of-flight SANS is suitable for studying the shapes and sizes of colloidal systems. High-pressure SANS (HP-SANS) is a particularly important technique for determining aggregate nanostructure in supercritical $\mathrm{CO}_{2}$. The HP-SANS measurements of the $\mathrm{D}_{2} \mathrm{O} /$ surfactant $/ \mathrm{scCO}_{2}$ systems were performed at $45^{\circ} \mathrm{C}$ at various pressures. The SANS2D time-of- 
flight instrument, at the Rutherford Appleton Laboratory at ISIS UK, was used in conjunction with a stirred, high-pressure cell (Thar). The path length in the cell and neutron beam diameter were both 10 $\mathrm{mm}$. The measurements gave absolute scattering cross sections $I(Q)\left(\mathrm{cm}^{-1}\right)$ as a function of momentum transfer $Q\left(\AA^{-1}\right)$, which is defined as $Q=(4 \pi / \lambda) \sin (\theta / 2)$, where $\theta$ is the scattering angle. The accessible $Q$ range was $0.002-1 \AA^{-1}$ on SANS2D arising from an incident neutron wavelength, $\lambda$, of $2.2-10 \AA$. The data were normalized for transmission, empty cell, solvent background, and pressure induced changes in cell volume as before ${ }^{15,22}$.

Pre-determined amounts of $\mathrm{D}_{2} \mathrm{O}$ and surfactant, where the molar ratio of surfactant to $\mathrm{CO}_{2}$ was fixed at $8.0 \times 10^{-4}(=16.7 \mathrm{mM}$ at the appropriate experimental condition), were loaded into the Thar cell. Then, $\mathrm{CO}_{2}(11.3 \mathrm{~g})$, was introduced into the cell by using a high-pressure pump, and the surfactant $/ \mathrm{D}_{2} \mathrm{O} / \mathrm{CO}_{2}$ mixture was pressurized to 350 bar at $45^{\circ} \mathrm{C}$ by decreasing the inner volume of the Thar cell. With vigorous stirring, visual observation was carried out to identify the mixture as being a transparent single-phase $\left(\mathrm{W} / \mathrm{CO}_{2} \mu \mathrm{E}\right)$ or a turbid phase. Finally, the HP-SANS experiments were performed for not only single-phase $\mathrm{W} / \mathrm{CO}_{2} \mu \mathrm{Es}$, but also the turbid phases formed below the cloud point phase transition pressure $P_{\text {trans. }}$ Due to the systems being dilute dispersions (volume fractions typically 0.012 or less), the physical properties of the continuous phase of $\mathrm{scCO}_{2}$ were assumed to be equivalent to those of pure $\mathrm{CO}_{2}$. Scattering length densities of reversed micelle shells $\left(\rho_{\text {shell }}\right)$, aqueous cores $\left(\rho_{\text {core }}\right)$, and $\mathrm{CO}_{2}\left(\rho_{\mathrm{CO} 2}\right)$ in the $\mathrm{D}_{2} \mathrm{O} / \mathrm{CO}_{2} \mu \mathrm{E}$ were calculated as $\rho_{\text {shell }}=2.28 \times 10^{10} \mathrm{~cm}^{-2}, \rho_{\text {core }}=4.92 \times 10^{10} \mathrm{~cm}^{-2}$, and $\rho_{\mathrm{CO} 2}=2.29 \times 10^{10} \mathrm{~cm}^{-2}$ as shown in supporting information (see $\mathbf{S 4}$ ). As $\rho_{\text {shell }}$ was close to $\rho_{\mathrm{CO} 2}$ and the shells are solvated with $\mathrm{CO}_{2}$ to get both scattering length densities closer, neutron scattering from the shells was identified to be negligible. Therefore, SANS from the $\mathrm{D}_{2} \mathrm{O} / \mathrm{CO}_{2} \mu$ Es was assumed to only be from the so-called aqueous core contrast. For model fitting data analysis, the $\mathrm{W} / \mathrm{CO}_{2} \mu \mathrm{E}$ droplets were treated as spherical or ellipsoidal particles with a Schultz distribution in core radii ${ }^{42}$. The polydispersities in spherical and ellipsoid radii were fixed at 0.3 as found in spherical $\mathrm{D}_{2} \mathrm{O} / \mathrm{CO}_{2} \mu$ Es with the double FCtail surfactants (polydispersity $=0.17-0.40)^{43}$. Full accounts of the scattering laws are given elsewhere ${ }^{15,22,}$ 
43. Data have been fitted to the models described above using the SasView small-angle scattering analysis software package (http://www.sasview.org/) ${ }^{44}$. The fitted parameters are the core radii perpendicular to the rotation axis $\left(R_{\mathrm{f}-\mathrm{ell}, \mathrm{a}}\right)$ and along the rotation axis $\left(R_{\mathrm{f}-\mathrm{ell}, \mathrm{b}}\right)$ for ellipsoidal particles, or the core radius $R_{\mathrm{sph}}$ for spherical particles; these values were initially obtained by preliminary Guinier analysis $\left(R_{\mathrm{g} \text {-sph }}\right)^{45}$.

Catanionic surfactant micelles in water were also characterized by ambient pressure SANS measurement and the data analysis. The SANS measurements were performed on D33 SANS instrument at the Institut Laue-Langevin (ILL, Grenoble, France), with a wavelength of $\lambda=6 \AA$ and two sample detector positions ( 2 and $7.5 \mathrm{~m}$ ) providing an accessible $Q$ range of $0.005-0.2 \AA^{-1}$. All samples were made in $\mathrm{D}_{2} \mathrm{O}$ using $2 \mathrm{~mm}$ path length rectangular quartz cells at $25^{\circ} \mathrm{C}$. Raw SANS data were reduced by subtracting the scattering of the empty cell and $\mathrm{D}_{2} \mathrm{O}$ background to an appropriate standard using the instrument-specific software. The SANS data analysis for catanionic surfactant micelles assumed that neutron scattering occurred from FC-cores and HC-shells in the micelles due to the large differences between the scattering length densities $\rho_{\mathrm{FC}}, \rho_{\mathrm{HC}}$ and $\rho_{\mathrm{D} 2 \mathrm{O}}\left(\rho_{\mathrm{FC}}=3.58 \times 10^{10} \mathrm{~cm}^{-2}\right.$, $\rho_{\mathrm{HC}}=-0.30 \times 10^{10} \mathrm{~cm}^{-2}$, and $\rho_{\mathrm{D} 2 \mathrm{O}}=6.32 \times 10^{10} \mathrm{~cm}^{-2}$ as shown in supporting information S4). Then SANS data for micelles in $\mathrm{D}_{2} \mathrm{O}$ were analysed with theoretical curves for a core/shell cylinder/disk particle form factor $^{46}$ with square well structure factor.

\section{Results and Discussion}

\section{Effects of catanionic surfactant structure on interfacial properties and micelle formation in water}

To investigate effects of catanionic surfactant structures on dilute aqueous phase properties, namely critical micelle concentration $(\mathrm{CMC})$ and the surface tension at $\mathrm{CMC}\left(\gamma_{\mathrm{CMC}}\right)$, surface tensions of aqueous surfactant solutions were measured at $23{ }^{\circ} \mathrm{C}$ as a function of surfactant concentration. Tensiometric data are displayed in Figure 1 and interfacial properties (CMC and $\gamma_{\mathrm{CMC}}$ ) estimated from these data are listed in Table 2. The surface tension data and interfacial properties of $\left[\mathrm{C}_{6} \mathrm{~F}_{13} \operatorname{mim}\right]\left[\mathrm{C}_{6} \mathrm{~F}_{13} \mathrm{~S}\right]$ and $\left[\mathrm{C}_{5} \mathrm{~F}_{11} \mathrm{mim}\right]\left[\mathrm{C}_{5} \mathrm{~F}_{11} \mathrm{~S}\right]$ shown in the figure and the table were previously reported ${ }^{35}$. All the catanionic surfactants effectively and efficiently lowered aqueous surface tension, and finally achieved the very low limiting value at the $\mathrm{cmc}$ of $\gamma_{\mathrm{CMC}}$ of $13.5-16.8 \mathrm{mN} / \mathrm{m}$ at concentrations $<1 \mathrm{mM}$. From the table, the CMC 
was found to decrease with increasing total fluorine content, as expected. ${ }^{9-15}$ The lowest surface tension and CMC are respectively lower by $\sim 9 \mathrm{mN} / \mathrm{m}$ and $\sim 100$ times than the parent anionic single FC-tail surfactants with a sodium counterion. These results clearly demonstrate synergistic effects of surfactant anion-cation pairing on surface activity and surface tension lowering in water. It suggests that a higher hydrophobicity and more densely-packed surfactant monolayers at air/water surface are generated by surfactant anion-cation pairing as compared to the parent surfactants.

Nanostructures of catanionic surfactant micelles in $\mathrm{D}_{2} \mathrm{O}$ were examined at a surfactant concentration of 20 x CMC by SANS measurements (Figure 2). All the SANS profiles have extensive regions of $Q^{-2}$ scattering. In the low $Q$ region, scattering may follow $I(Q) \sim Q^{-D}$, where $D$ is a distinctive "mass fractal" for the micellar particles; hence, the slope of a log-log plot will be $-D$. In the case of noninteracting spheres, $D$ should be zero in this low $Q$ region, whereas $D=1$ for cylinders and 2 for disks. ${ }^{45}$ In the cases of catanionic surfactant micelles, the slope of $Q^{-2}$ suggests the formation of 2-dimensional disk-like micelles or vesicles.

One approach to obtain average radii from SANS data for the globular and disk-like micelles is via Guinier $\operatorname{plot}^{35}\left(\operatorname{Ln}[I(Q)]\right.$ vs $\left.Q^{2}\right)$ as displayed in supporting information (Figure S2). In the all plots of $\operatorname{Ln}[I(Q)]$ vs $Q^{2}$, linearity was noted over an extended $Q$-range, and the slopes enabled calculation of radii of gyration, $R_{\mathrm{g}}$ (the slope $=-R_{\mathrm{g}}{ }^{2} / 3$ ). This $R_{\mathrm{g}}$ may also be related to a principal disk radius $R_{\mathrm{g}}$-disk as $R_{\mathrm{g}}=$ $4^{-0.5} R_{\mathrm{g}-\text { disk }}{ }^{45}$ The $R_{\mathrm{g}-\text { disk }}$ values are listed in Table $\mathbf{S 1}$ along with $R_{\mathrm{g}}$ values. Porod analyses of SANS data was also carried out as shown in Figure S3, and the sphere radius $\left(R_{\mathrm{p}-\mathrm{sph}}\right)$ obtained from the $Q$ value at $1^{\text {st }}$ maximum was also listed in Table $\mathbf{S 1}$ as a reference.

The values of disk radii $R_{\mathrm{g} \text {-disk }}$ provided by Guinier analysis were used as the starting points for model fitting with the core/shell disk/cylinder form factor models and an additional square well structure factor. [Note the "cylinder" form factor model is quite general, and by inverting the aspect ratio can be used to simulate scattering from disk-like particles]. A square well structure factor was used for obtaining better fits to the SANS data at low $Q$ values $<0.02 \AA^{-1}$ as discussed in supporting information S6. The fitted parameters for disk-like FC-core radius $\left(R_{\mathrm{f}-\mathrm{Cdisk}}\right)$ and thickness $\left(t_{\mathrm{f}-\mathrm{Cdisk}}\right), \mathrm{HC}$-shell thickness $\left(t_{\mathrm{f}-\mathrm{Sdisk}}\right)$, 
aspect ratio, well depth and width are listed in Table 3. Cloud point temperatures at the concentrations of $20 \times \mathrm{CMC}$ were determined by visual observation as shown in supporting information $\mathbf{S 7}$ and are also listed in the table.

At these concentrations, the cloud temperature of FC-branched catanionic surfactant $\left[\mathrm{C}_{6} \mathrm{~F}_{13} \mathrm{mim}\right]\left[\left(\mathrm{CF}_{3}\right)_{3} \mathrm{~S}\right]$ was $\sim 30^{\circ} \mathrm{C}$, hence stabilizing a clear single solution at room temperature. However, that of the non-FC-branched surfactant $\left[\mathrm{C}_{5} \mathrm{~F}_{11} \mathrm{mim}\right]\left[\mathrm{C}_{5} \mathrm{~F}_{11} \mathrm{~S}\right]$ was below $0{ }^{\circ} \mathrm{C}$, giving a translucent solution implying presence of larger aggregates (e.g. vesicles) ${ }^{23-26}$. Actually, the SANS profiles for $\left[\mathrm{C}_{5} \mathrm{~F}_{11} \mathrm{mim}\right]\left[\mathrm{C}_{5} \mathrm{~F}_{11} \mathrm{~S}\right]$ and $\left[\mathrm{C}_{6} \mathrm{~F}_{13} \mathrm{mim}\right]\left[\mathrm{C}_{6} \mathrm{~F}_{13} \mathrm{~S}\right]$ can be fitted with the theoretical curves for spherical vesicles having radius larger than $100 \mathrm{~nm}$ and micro-segregated FC and HC layers, although that for $\left[\mathrm{C}_{6} \mathrm{~F}_{13} \mathrm{mim}\right]\left[\left(\mathrm{CF}_{3}\right)_{3} \mathrm{~S}\right]$ cannot, as shown in supporting information (Fig. S6 for log-log plots, Fig. S7 for lin-lin plots, and Table S3 for the structure parameter estimated for the vesicles). However, better fits were obtained using the disk model as compared to the vesicle model. The discussion below addresses the structure parameters applied to the of disk model.

In the Table 3, the structure factor $(S(Q))$ parameters for well depth and width, were almost same for $\left[\mathrm{C}_{5} \mathrm{~F}_{11} \mathrm{mim}\right]\left[\mathrm{C}_{5} \mathrm{~F}_{11} \mathrm{~S}\right]$ and $\left[\mathrm{C}_{6} \mathrm{~F}_{13} \mathrm{mim}\right]\left[\mathrm{C}_{6} \mathrm{~F}_{13} \mathrm{~S}\right]$. However, the depth and the width for $\left[\mathrm{C}_{6} \mathrm{~F}_{13} \mathrm{mim}\right]\left[\left(\mathrm{CF}_{3}\right)_{3} \mathrm{~S}\right]$ was smaller and larger than those of straight chain surfactants, respectively. This suggests the attractive interactions between $\left[\mathrm{C}_{6} \mathrm{~F}_{13} \mathrm{mim}\right]\left[\left(\mathrm{CF}_{3}\right)_{3} \mathrm{~S}\right]$ micelles are not so strong. These results are consistent with the difference in cloud temperature between $\left[\mathrm{C}_{6} \mathrm{~F}_{13} \mathrm{mim}\right]\left[\left(\mathrm{CF}_{3}\right)_{3} \mathrm{~S}\right]$ and $\left[\mathrm{C}_{5} \mathrm{~F}_{11} \mathrm{mim}\right]\left[\mathrm{C}_{5} \mathrm{~F}_{11} \mathrm{~S}\right]$, namely the higher cloud temperature of $\left[\mathrm{C}_{6} \mathrm{~F}_{13} \mathrm{mim}\right]\left[\left(\mathrm{CF}_{3}\right)_{3} \mathrm{~S}\right]$ indicates a weaker hydrophobicity and weaker attractive inter-micellar interactions.

Focusing on thicknesses of the disk-like FC-core $t_{\mathrm{f}-\text { Cdisk }}$ and HC-shell $t_{\mathrm{f} \text {-Shell }}$, the total diskthickness $\left(t_{\mathrm{f}-\mathrm{Cdisk}}+2 t_{\mathrm{f}-\mathrm{Shell}}\right)$ values are similar to twice the hydrophobic tail length of the catanionic surfactants (13.6 $\AA$ for $\left[\mathrm{C}_{6} \mathrm{~F}_{13} \mathrm{~S}\right], 12.3 \AA$ for $\left[\mathrm{C}_{6} \mathrm{~F}_{13} \mathrm{mim}\right]$ and $\left[\mathrm{C}_{5} \mathrm{~F}_{11} \mathrm{~S}\right], 11.0 \AA$ for $\left[\mathrm{C}_{5} \mathrm{~F}_{11} \mathrm{mim}\right]$, and $7.1 \AA$ for $\left[\left(\mathrm{CF}_{3}\right)_{3} \mathrm{~S}\right]$ ) as obtained by the MM2 calculation (Figure $\mathbf{S} 7$ in supporting information), suggesting a bilayer cross-section structure of the disk-like micelles. On the other hand, the disk core radius $R_{\mathrm{f}-\mathrm{Cdisk}}$ increased in the order of $\left[\mathrm{C}_{6} \mathrm{~F}_{13} \mathrm{mim}\right]\left[\left(\mathrm{CF}_{3}\right)_{3} \mathrm{~S}\right]<\left[\mathrm{C}_{6} \mathrm{~F}_{13} \mathrm{mim}\right]\left[\mathrm{C}_{6} \mathrm{~F}_{13} \mathrm{~S}\right]<\left[\mathrm{C}_{5} \mathrm{~F}_{11} \mathrm{mim}\right]\left[\mathrm{C}_{5} \mathrm{~F}_{11} \mathrm{~S}\right]$. the 
radial dimensions of disk-like micelles are known to increase with increasing difference in Gibbs energy between the edge (hemi-rod-like micelle) and the main body (bilayer) ${ }^{47,48}$, i.e. a larger disk radius generated with energy of the edge $>>$ main body. For catanionic surfactants, a combination of straight FC-chains is likely to promote growth of disk-like micelles with an increasing energy difference. ${ }^{23-26}$

Taken together, these results showing formation of disk-like micelles in water implies the catanionic surfactants have sufficiently high CPP values suitable for forming reverse micelles. In addition, the low $\mathrm{CMC}$ values $<1 \mathrm{mM}$ and very low $\gamma_{\mathrm{CMC}}$ of $13.5-16.8 \mathrm{mN} / \mathrm{m}$ suggests a low HLB and high surface activity of these catanionic surfactants. All of these features suggest a low hydrophilic- $\mathrm{CO}_{2}$-philic balance (HCB $)^{49,50}$ and good affinity to $\mathrm{scCO}_{2}$, which are promising characteristics for stabilizing $\mathrm{W} / \mathrm{CO}_{2} \mu \mathrm{Es}$.

\section{Effect of catanionic surfactant structure on stabilization of reverse micelles and microemulsions in $\mathrm{seCO}_{2}$}

To examine phase behaviour of catanionic surfactant/water $/ \mathrm{CO}_{2}$ mixtures in detail, the pressures at which clear single phases start to appear cloudy, $P_{\text {trans }}$, were measured for water/surfactant $/ \mathrm{CO}_{2}$ mixtures at temperatures of $35-75^{\circ} \mathrm{C}$ and $W_{0}$ values of $6-84$. Figure 3 shows phase diagrams in terms of $P_{\text {trans }}$ and $\mathrm{CO}_{2}$ density for $\left[\mathrm{C}_{6} \mathrm{~F}_{13} \mathrm{mim}\right]\left[\mathrm{C}_{6} \mathrm{~F}_{13} \mathrm{~S}\right] /$ water $/ \mathrm{CO}_{2}$ mixtures with each $W_{0}$ value at [surfactant $] /\left[\mathrm{CO}_{2}\right]=8 \times 10^{-4}$ as a function of temperature. At values higher than $P_{\text {trans, }},\left[\mathrm{C}_{6} \mathrm{~F}_{13}\right.$ mim $]\left[\mathrm{C}_{6} \mathrm{~F}_{13} \mathrm{~S}\right]$ with $[$ surfactant $] /\left[\mathrm{CO}_{2}\right]=8 \times 10^{-4}$ with added water gave stable transparent systems in $\mathrm{scCO}_{2}$. However, the other catanionic surfactants $\left[\mathrm{C}_{5} \mathrm{~F}_{11} \mathrm{mim}\right]\left[\mathrm{C}_{5} \mathrm{~F}_{11} \mathrm{~S}\right]$ and $\left[\mathrm{C}_{6} \mathrm{~F}_{13} \mathrm{mim}\right]\left[\left(\mathrm{CF}_{3}\right)_{3} \mathrm{~S}\right]$ always remained turbid phases or two-phase, even at the highest pressure and temperature 400 bar and $75^{\circ} \mathrm{C}$. A simple mixture of the individual surfactants $\mathrm{Na}\left[\mathrm{C}_{6} \mathrm{~F}_{13} \mathrm{~S}\right]$ and $\mathrm{MeS}\left[\mathrm{C}_{6} \mathrm{~F}_{13} \mathrm{mim}\right]$ was also tested for formation of W/CO $2 \mu \mathrm{E}$. Interestingly, the surfactant mixture was almost insoluble in $\mathrm{scCO}_{2}$. This is probably due to the low solubility of both the single-tail surfactants compared with the catanionic surfactant. This result suggests that formation of the catanionic surfactant beforehand, namely ion-pairing the parent surfactants and removing the counterion salt $(\mathrm{NaMeS})$, is important to generate the good solubility and $\mathrm{W} / \mathrm{CO}_{2}$ microemulsion formation. 
With increasing temperature from $35^{\circ} \mathrm{C}$ to $75^{\circ} \mathrm{C}, P_{\text {trans }}$ increased by $80-110$ bar but the $\mathrm{CO}_{2}$ density decreased by $0.9-1.3 \mathrm{~g} \mathrm{~cm}^{-3}$. Solubility of a compound in $\mathrm{scCO}_{2}$ is known to mainly depend on $\mathrm{CO}_{2}$ density (rather than pressure per say), resulting in an increase in solvating $\mathrm{CO}_{2}$ molecules. ${ }^{1-16}$ Higher temperatures (higher thermal motion and weaker interactions between surfactant molecules) are expected to enable generation of $\mathrm{W} / \mathrm{CO}_{2}$ microemulsion at lower $\mathrm{CO}_{2}$ densities. ${ }^{1-16}$ Increasing $W_{0}$ feeds through to an increase in $P_{\text {trans }}\left(W_{0}=36\right.$ from to 48$)$. Significant increase in $P_{\text {trans }}$ with increasing $W_{0}$ was also reported in the use of high $\mathrm{HCB}$ surfactants like $\mathrm{CO}_{2}$-soluble $\mathrm{HC}$-surfactants or short FC-surfactants (e.g. $\mathrm{CF}_{3}\left(\mathrm{CF}_{2}\right)_{n^{-}}$with $\left.n=0-3\right)^{41}$, and it could be caused by greater $\mathrm{CO}_{2}$ solvation of the surfactant tails. ${ }^{1-16}$ Based on the phase behaviour observations, transparent phases identified as $\mathrm{W} / \mathrm{CO}_{2} \mu$ Es were observed at pressures $>260$ bar $\left(\mathrm{CO}_{2}\right.$ density $\left.>0.84 \mathrm{~g} \mathrm{~cm}^{-3}\right)$, even with the very high $W_{0}$ value of 84 . However, this is not really clear evidence for formation of Winsor IV-type $\mathrm{W} / \mathrm{CO}_{2} \mu$ Es at these large $W_{0}$ values (up to 84), and it is possible that transparent phases with high $W_{0}$ values may be Winsor II-type (albeit with the excess water phase out of view, and below the pressure cell windows).

Comparing the $P_{\text {trans }}$ values at $W_{0}=10$ for the double-FC-tail surfactants $n \mathrm{FS}(\mathrm{EO})_{2}$ and $n \mathrm{FG}(\mathrm{EO})_{2}$ $(n=4,6,8)$ as shown in Figure $\mathbf{S 9}$ (supporting information) ${ }^{14}$, to those at $W_{0}=12$ for $\left[\mathrm{C}_{6} \mathrm{~F}_{13} \operatorname{mim}\right]\left[\mathrm{C}_{6} \mathrm{~F}_{13} \mathrm{~S}\right]$ shows they are quite similar, especially to $6 \mathrm{FG}(\mathrm{EO})_{2}$. It suggests the same FC-length surfactants $\left[\mathrm{C}_{6} \mathrm{~F}_{13} \mathrm{mim}\right]\left[\mathrm{C}_{6} \mathrm{~F}_{13} \mathrm{~S}\right]$ and $6 \mathrm{FG}(\mathrm{EO})_{2}$ have similar $\mathrm{CO}_{2}$-philicity (or $\mathrm{HCB}$ ) and ability to stabilize $\mathrm{W} / \mathrm{CO}_{2}$ $\mu E s$, even with different types of headgroups (anionic sulfonate for $6 \mathrm{FG}(\mathrm{EO})_{2}$ and anionic sulfonate + cationic methylimidazolium for the catanionic).

The appearance of transparent single-phases with high $W_{0}$ values $>10$ is consistent with the formation of $\mathrm{W} / \mathrm{CO}_{2} \mu \mathrm{Es}$. To explore formation of hydrogen bonded $\mu \mathrm{E}$ water cores, FT-IR spectra were recorded of $16.7 \mathrm{mM}$ surfactant $/ \mathrm{H}_{2} \mathrm{O} / \mathrm{CO}_{2}$ mixtures with different $W_{0}$ values at 350 bar and $45^{\circ} \mathrm{C}$ (Figures 4 and S10). Typically, the O-H stretching vibration in a non-polar solvent appears $\sim 3630 \mathrm{~cm}^{-1}$ but can shift to lower wavenumbers depending on the hydrogen bond environment. ${ }^{52,53}$ A seen in Figures 4 and S10 absorbance over $3100-3500 \mathrm{~cm}^{-1}$ in the FT-IR spectra increased with increasing added water $W_{0}$. These spectra and the changes with increasing $W_{0}$ are very similar to those for $\mathrm{W} / \mathrm{CO}_{2} \mu \mathrm{Es}$ formed by 
anionic fluorinated surfactants $\mathrm{FC} 6-\mathrm{HC} 4$ and $8 \mathrm{FS}(\mathrm{EO})_{2}{ }^{53}$ The absorbance for the $\left[\mathrm{C}_{6} \mathrm{~F}_{13} \mathrm{mim}\right]\left[\mathrm{C}_{6} \mathrm{~F}_{13} \mathrm{~S}\right] / \mathrm{W} / \mathrm{CO}_{2} \mu \mathrm{Es}$ grew with $W_{0}$ up until $W_{0}=50$, suggesting a maximum watersolubilizing power $W_{0}{ }^{\max } \sim 50$. In contrast with the behavior for $\left[\mathrm{C}_{6} \mathrm{~F}_{13} \mathrm{mim}\right]\left[\mathrm{C}_{6} \mathrm{~F}_{13} \mathrm{~S}\right]$, there were no changes in FT-IR spectra for $\left[\mathrm{C}_{6} \mathrm{~F}_{13} \mathrm{mim}\right]\left[\left(\mathrm{CF}_{3}\right)_{3} \mathrm{~S}\right]$ and $\left[\mathrm{C}_{5} \mathrm{~F}_{11} \mathrm{mim}\right]\left[\mathrm{C}_{5} \mathrm{~F}_{11} \mathrm{~S}\right]$ even on increasing $W_{0}$ from 10.2 up to 30.6 (Fig. S10). The parent surfactant with a sodium counterion $\mathrm{Na}\left[\mathrm{C}_{6} \mathrm{~F}_{13} \mathrm{~S}\right]$ did not show any clear absorbance in the water $\mathrm{OH}$ stretching region (Fig. S10).

It is intriguing why $\left[\mathrm{C}_{6} \mathrm{~F}_{13} \mathrm{mim}\right]\left[\mathrm{C}_{6} \mathrm{~F}_{13} \mathrm{~S}\right]$ can stabilize $\mu$ Es whereas the other surfactants do not, especially since the differences in chemical structures are so small: just two more $-\mathrm{CF}_{2}$ - units for $\left[\mathrm{C}_{6} \mathrm{~F}_{13} \mathrm{mim}\right]\left[\mathrm{C}_{6} \mathrm{~F}_{13} \mathrm{~S}\right]$ compared to the other catanionics. The longer fluorocarbon tails of $\left[\mathrm{C}_{6} \mathrm{~F}_{13} \mathrm{mim}\right]\left[\mathrm{C}_{6} \mathrm{~F}_{13} \mathrm{~S}\right]$ are expected to produce a higher $\mathrm{CO}_{2}$-philicity and a higher solubility in $\mathrm{scCO}_{2} \cdot{ }^{1-16}$ Hence, the total number of fluorinated carbons $C_{12}$ per surfactant may represent a lower limit for the catanionic surfactant to achieve good compatibility with $\mathrm{scCO}_{2}$, whereas a smaller number of fluorinated carbons is insufficient. With an impressive water-solubilizing power $W_{0} \max =\sim 50$ of $\left[\mathrm{C}_{6} \mathrm{~F}_{13} \operatorname{mim}\right]\left[\mathrm{C}_{6} \mathrm{~F}_{13} \mathrm{~S}\right]$ can be identified as a superefficient $\mathrm{CO}_{2}$-philic surfactant for $\mathrm{W} / \mathrm{CO}_{2} \mu \mathrm{Es}$, at least comparable to the best performance reported to date with $8 \mathrm{FG}(\mathrm{EO})_{2} \cdot{ }^{1-16}$ This appears to be the first case of a highly effective $\mathrm{CO}_{2}$-philic surfactant based on ion-pairing of anionic and cationic single FC-tail surfactants, and especially interesting for its environmental acceptability.

To demonstrate the $\left[\mathrm{C}_{6} \mathrm{~F}_{13} \mathrm{mim}\right]\left[\mathrm{C}_{6} \mathrm{~F}_{13} \mathrm{~S}\right] / \mathrm{D}_{2} \mathrm{O} / \mathrm{CO}_{2} \mu$ Es, SANS $I(Q)$ profiles were obtained at $W_{0}$ $=20,45^{\circ} \mathrm{C}$ and 350 bar. SANS data along with the fitted $I(Q)$ functions are plotted in Figure 5 (or Figure S11). This $W_{0}$ value was chosen for comparison with the SANS data of a related double FC-tail surfactant (i.e. $n \mathrm{FG}(\mathrm{EO})_{2}$ and $\left.n \mathrm{FS}(\mathrm{EO})_{2}\right) / \mathrm{W} / \mathrm{CO}_{2}$ microemulsions with $W_{0}=20$ reported earlier. ${ }^{14}$ The transparent single-phase displayed a SANS profile consistent with nano-scale $\mathrm{D}_{2} \mathrm{O}$ droplets, and in the low $Q$ region $<0.01 \AA^{-1}$ the SANS profiles showed $D=\sim 0$, suggesting the presence of globular nanodomains. To obtain approximate $\mu \mathrm{E}$ core dimensions Guinier ${ }^{45}$ and Porod plots ${ }^{54}$ were prepared to estimate $R_{\mathrm{g}}$ and $R_{\mathrm{p}}$ sph values (see supporting information Figure S12). Principal sphere radii $R_{\mathrm{g}}$-sph were also obtained using $R_{\mathrm{g}}$ $=(3 / 5)^{0.5} R_{\mathrm{g}}{ }_{\text {-sph }}{ }^{45}$, and values of $R_{\mathrm{g}}, R_{\mathrm{g}}{ }^{- \text {sph }}$ and $R_{\mathrm{p}^{-} \text {sph }}$ are displayed in Fig. S12. The polydisperse Schultz 
spherical model was employed at first for the analysis but did not fit well the SANS data at low $Q<0.03$ $\AA^{-1}$ (Fig. S11). Hence, to test for other possible globular shapes, these $R_{\mathrm{g}}$ sph values were employed as starting points for model fit analyses using a polydisperse Schultz ellipsoid form factor (oblate and prolate shapes). Theoretical curves of both ellipsoid models fitted well and gave similar fit qualities: the parameter outputs $R_{\mathrm{f}-\mathrm{ell}, \mathrm{a}}$ and $R_{\mathrm{f}-\mathrm{ell}, \mathrm{b}}$ shown in Fig. 5 are the average radii for oblate $\mathrm{D}_{2} \mathrm{O}$ cores. Aspect ratios for the $\mathrm{D}_{2} \mathrm{O}$ cores $\left(X_{\text {core }}=R_{\text {ell-b }} / R_{\text {ell }-\mathrm{a}}\right)$ and reverse micelles $\left(X_{\mathrm{RM}}=\left\{R_{\mathrm{ell}-\mathrm{b}}+l_{\mathrm{c}}\right\} /\left\{R_{\text {ell- } \mathrm{a}}+l_{\mathrm{c}}\right\}\right.$, where $l_{\mathrm{c}}$ is the average hydrophobic tail length $13 \AA$ ) were calculated as $X_{\text {core }}=0.545$ and $X_{\mathrm{RM}}=0.683$ for oblate and $X_{\text {core }}=2.19$ and $X_{\mathrm{RM}}=1.71$ for prolate types. Some earlier papers ${ }^{15,22}$ found anisotropic reverse micelles to form in $\mathrm{scCO}_{2}$, and increase $\mathrm{CO}_{2}$ viscosity. In the most effective case, $\mathrm{CO}_{2}$ viscosity was expected to increase by three times with rod-like reverse micelles having a rod-length of $\sim 880 \AA .{ }^{15}$

There is known to be a clear trend in viscosity vs aspect ratio for nano-aggregates. To normalise for concentration, it is helpful to evaluate an intrinsic viscosity $[\eta]$ at infinite dilution. The values of $[\eta]$ and viscosity of reverse micelle $/ \mathrm{CO}_{2}$ solutions were estimated as follows ${ }^{15}$. The $[\eta]$ value is linked to aggregate shape, for hard spheres $[\eta]=2.5$, whereas for one-dimensional, anisotropic particles $[\eta]$ is larger than this and can be calculated using equation $(1)^{55,56}$ :

$$
[\eta]=2.5+0.4075\left(X_{\text {micelle }}-1\right)^{1.508}
$$

where $X_{\text {micelle }}$ is the aggregate aspect ratio (which can be obtained by analyses of SANS data). Next [ $\left.\eta\right]$ allows estimation of $\eta_{\text {sp }}$ using structural parameters from SANS analyses, and the known sample volume fraction $\phi_{\mathrm{p}}$. As such, equation (2) offers an approximate formula which is appropriate for the dilute system of $\phi_{\mathrm{p}}<0.2$ : viscosities calculated by this approach have been demonstrated to coincide with experimental values ${ }^{57}$.

$$
\eta_{\mathrm{sp}}=[\eta] \phi_{\mathrm{p}}+K_{\mathrm{H}}[\eta]^{2} \phi_{\mathrm{p}}^{2}
$$

where the $K_{\mathrm{H}}$ is the Huggins coefficient for rods (in this case $\sim 0.4$ ) ${ }^{56}$, calculated from the shear rate and rotational diffusion coefficient $D_{\text {rot; }}$ shear rate being obtained by analytical solution of the Navier-Stokes equation and $D_{\text {rot }}$ being estimated from the SANS structural parameters and neat solution viscosity. As the $\left[\mathrm{C}_{6} \mathrm{~F}_{13} \mathrm{mim}\right]\left[\mathrm{C}_{6} \mathrm{~F}_{13} \mathrm{~S}\right]$ molecular volume was estimated to be $750 \AA^{3}$ from $v_{\mathrm{FC}}=332 \AA^{3}, v_{\mathrm{HC}}=167 \AA^{3}$ 
$v_{\text {sulf }}=117 \AA^{3}$ and $v_{\text {mim }}=134 \AA^{3}$ in the experimental section (Sec. 2.4), the required volume fraction $\phi_{\mathrm{p}}$ of reverse micelles with aqueous cores was calculated as $1.36 \times 10^{-2}$ based on the known concentrations of surfactant and $\mathrm{D}_{2} \mathrm{O}$. On the assumption that prolate reverse micelles form, equation (1) and (2) gave [ $\left.\eta\right]$ $=2.74$ and $\eta_{\mathrm{sp}}=0.038$ for the prolate $\mathrm{W} / \mathrm{CO}_{2} \mu \mathrm{E}$, suggesting viscosity enhancement of $\mathrm{CO}_{2}$ by $\sim 4 \%$. Unfortunately, it is not a significant $\mathrm{CO}_{2}$-thickening ability due to the low surfactant concentration and the $W_{0}$ value. As found with different fluorinated surfactants ${ }^{15}$, the viscosity enhancement may improve at higher surfactant concentration and optimal $W_{0}$ values by formation of long rod-like reverse micelles, which might be employed to enhance sweep efficiency in $\mathrm{CO}_{2}$-enhanced oil recovery (EOR). ${ }^{15}$

Previous SANS studies ${ }^{15,43}$, with $\mathrm{W} / \mathrm{CO}_{2} \mu$ Es stabilized by double FC-tail surfactants $\left(n \mathrm{FG}(\mathrm{EO})_{2}\right.$ and $\left.n \mathrm{FS}(\mathrm{EO})_{2}\right)$ and different $\mathrm{FC}$ lengths $(n=4$ and 8$)$ found spherical $\mathrm{D}_{2} \mathrm{O}$ cores of radius $R=17.9-18.9$ at $W_{0}=20-22,45^{\circ} \mathrm{C}$, and 350 bar. When comparing double $\mathrm{FC}$-tail surfactants and $\left[\mathrm{C}_{6} \mathrm{~F}_{13} \operatorname{mim}\right]\left[\mathrm{C}_{6} \mathrm{~F}_{13} \mathrm{~S}\right]$ $\left(\left(R_{\text {ell-a }}^{2} R_{\text {ell-b }}\right)^{1 / 3}=24.4-24.8 \AA\right)$, the core radius for the catanionic surfactant is $1.3-1.4$ times larger. The larger aqueous cores (i.e. the smaller negative curvature of $\mathrm{W} / \mathrm{CO}_{2}$ interface) suggests the catanionic has a smaller effective CPP value and/or a larger aggregation number. ${ }^{15,} 31,32,43$ Considering both $n \mathrm{FG}(\mathrm{EO})_{2}$ and $\left[\mathrm{C}_{6} \mathrm{~F}_{13} \mathrm{mim}\right]\left[\mathrm{C}_{6} \mathrm{~F}_{13} \mathrm{~S}\right]$ to be di-FC-chain surfactant molecules, differences in CPP and/or aggregation number are likely to come from the headgroup structure and interactions, i.e. electrostatic interactions between the anionic and catanionic headgroups, respectively. ${ }^{23-30}$

\section{Conclusions}

$\mathrm{W} / \mathrm{CO}_{2}$ microemulsions $\left(\mathrm{W} / \mathrm{CO}_{2} \mu \mathrm{Es}\right)$ are potential universal green-solvents having both polar and nonpolar solvent properties, which can be used for various chemical applications as mentioned in the Introduction. ${ }^{2,3}$ Eventually, these $\mu$ Es will hopefully be available with low levels of surfactant, be costeffective and environmentally-friendly. Therefore, finding low F-content surfactants with high solubilizing power is key to developing useful $\mathrm{CO}_{2}$-philic surfactants.

Chemical industries using surfactants usually employ mixtures, surfactant/co-surfactant, surfactant/co-solvent or surfactant/other additives to obtain surfactant properties unavailable in only single surfactant systems. ${ }^{23-30,35-40}$ Such surfactant mixtures have also been tried in supercritical $\mathrm{CO}_{2}$, but 
with only limited success 53,58 : for example, in the case of a anionic hybrid surfactant FC6-HC4 mixed with an anionic double FC-tail surfactant $8 \mathrm{FS}(\mathrm{EO})_{2}$ the synergism was rather weak. ${ }^{53}$ Therefore, the usefulness of employing surfactant mixtures was unclear.

This study explored a new set of catanionic surfactants, which can be generally considered as "mixed surfactants". Most importantly, one of these compounds $\left[\mathrm{C}_{6} \mathrm{~F}_{13} \mathrm{mim}\right]\left[\mathrm{C}_{6} \mathrm{~F}_{13} \mathrm{~S}\right]$ represents the first successful case of a catanionic surfactant for stabilization of $\mathrm{W} / \mathrm{CO}_{2} \mu \mathrm{Es}$, furthermore, it has a high watersolubilizing power $\left(W_{0}^{\max }=\sim 50\right)$. It seems that a catanionic surfactant structure is a good way to generate a large CPP and a low $\mathrm{HCB}$ (hydrophilic- $\mathrm{CO}_{2}$-philic balance) required for stabilizing $\mathrm{W} / \mathrm{CO}_{2} \mu \mathrm{Es}$. This finding of the strong synergistic effects from surfactant anion-cation pairing could be a key advance in the design of mixed surfactant systems for $\mathrm{W} / \mathrm{CO}_{2} \mu \mathrm{Es}$.

Formation of $\mathrm{W} / \mathrm{CO}_{2} \mu \mathrm{Es}$ comprising shape-anisotropic reverse micelles could help access the next class of universal solvents with attractive characteristics. This is especially true if anisotropic reverse micelles with high aspect ratios can be formed, since they increase $\mathrm{CO}_{2}$ viscosity, which would help realize efficient EOR $\mathrm{CO}_{2}$-flooding ${ }^{15}$. Such anisotropic reverse micelles would also act as nanoreactors to produce anisotropic nanomaterials having interesting quantum effects.

Future efforts will be focused on effects of temperature pressure, and $W_{0}$ on solubilization of water and/or ionic substances, and aggregate nanostructures. This will help clarify how to generate synergistic effects with mixed catanionic systems by surfactant molecular design.

\section{ASSOCIATED CONTENT}

Supporting Information. Synthetic route to catanionic surfactants. Chemical structures of surfactants tested in earlier $\mathrm{W} / \mathrm{CO}_{2}$ microemulsion studies. Surface tension measurements of aqueous surfactant solutions. Calculation of scattering length densities for reversed micelle shells $\left(\rho_{\text {shell }}\right)$, aqueous cores $\left(\rho_{\text {core }}\right)$, and $\mathrm{CO}_{2}\left(\rho_{\mathrm{CO} 2}\right)$ in the $\mathrm{D}_{2} \mathrm{O} / \mathrm{CO}_{2} \mu$ Es. Estimation of radius of micelles in catanionic surfactant $/ \mathrm{D}_{2} \mathrm{O}$ solutions by Guinier and Porod analyses of SANS data. Use of square well structure form factor for SANS data from catanionic surfactant micelles in water. Cloud temperatures of catanionic surfactants in water. Comparison between theoretical curves with a core-shell cylinder/disk particle model (for disk-like 
micelles) and core-multi-shell spherical particle model (for vesicles) with SANS data from catanionic surfactant/water mixtures. Structures of steric models and tail lengths of surfactant ions employed in catanionic surfactants. $P_{\text {trans }}$ for $n \mathrm{FS}(\mathrm{EO})_{2}$ and $n \mathrm{FG}(\mathrm{EO})_{2} / \mathrm{W} / \mathrm{CO}_{2}$ mixtures. FT-IR spectra of $16.7 \mathrm{mM}$ surfactant/water $/ \mathrm{CO}_{2}$ mixtures with different $W_{0}$ values. Theoretical curves for spherical and ellipsoidal particles models fitted to the SANS profile of $16.7 \mathrm{mM}\left[\mathrm{C}_{6} \mathrm{~F}_{13} \mathrm{mim}\right]\left[\mathrm{C}_{6} \mathrm{~F}_{13} \mathrm{~S}\right] / \mathrm{D}_{2} \mathrm{O} / \mathrm{CO}_{2} \mu \mathrm{E}$ with $W_{0}=20$. Estimation of $\mathrm{D}_{2} \mathrm{O}$ core radius in $16.7 \mathrm{mM}\left[\mathrm{C}_{6} \mathrm{~F}_{13} \mathrm{mim}\right]\left[\mathrm{C}_{6} \mathrm{~F}_{13} \mathrm{~S}\right] / \mathrm{D}_{2} \mathrm{O} / \mathrm{CO}_{2}$ reversed micelles by Guinier and Porod analyses of SANS data.

This material is available free of charge via the Internet at "http://pubs.acs.org."

\section{AUTHOR INFORMATION}

Corresponding Author. *E-mail sagisaka@hirosaki-u.ac.jp; FAX +81-172-39-3579 (M.S.)

Notes. The authors declare no competing financial interest.

\section{ACKNOWLEDGEMENT}

This project was supported by JSPS [KAKENHI, Grant-in-Aid for Scientific Research (B), No. 26289345, Grant-in-Aid for Challenging Exploratory Research, No. 26630383, Grant-in-Aid for Challenging Research (Exploratory), No.17K19002], and Leading Research Organizations (RCUK [through EPSRC EP/I018301/1], ANR [13-G8ME-0003]) under the G8 Research Councils Initiative for Multilateral Research Funding-G8-2012. We also acknowledge STFC for the allocation of beam time, travel, and consumables grants at ISIS. The authors thank Pia McAleenan for synthesis of some compounds used in the study. 


\section{Figure Captions}

Figure 1. Change in surface tension of aqueous surfactant solutions as a function of surfactant concentration at $23 \pm 0.5{ }^{\circ} \mathrm{C}$ and 1 bar. Surface tension data for $\left[\mathrm{C}_{6} \mathrm{~F}_{13} \mathrm{mim}\right]\left[\mathrm{C}_{6} \mathrm{~F}_{13} \mathrm{~S}\right]$ and $\left[\mathrm{C}_{6} \mathrm{~F}_{13} \mathrm{mim}\right]\left[\mathrm{C}_{6} \mathrm{~F}_{13} \mathrm{~S}\right]$ are taken from an earlier paper. ${ }^{29}$

Figure 2. SANS profiles for surfactant $/ \mathrm{D}_{2} \mathrm{O}$ solutions at $\left[\right.$ surfactant] $=20 \times \mathrm{CMC}, 25^{\circ} \mathrm{C}$ and 1 bar. Solid lines are theoretical curves for core/shell disk form factor model with square well structure factor fitted to the experimental data (symbols).

Figure 3. Changes in $P_{\text {trans }}$ (top) and corresponding $\mathrm{CO}_{2}$ density (bottom) for $\left[\mathrm{C}_{6} \mathrm{~F}_{13} \operatorname{mim}\right]\left[\mathrm{C}_{6} \mathrm{~F}_{13} \mathrm{~S}\right]$ /water $/ \mathrm{CO}_{2}$ mixtures with different $W_{0}$ values at $[$ surfactant $] /\left[\mathrm{CO}_{2}\right]=8 \times 10^{-4}$ as a function of temperature.

Figure 4. FT-IR spectra of $16.7 \mathrm{mM}\left[\mathrm{C}_{6} \mathrm{~F}_{13} \mathrm{mim}\right]\left[\mathrm{C}_{6} \mathrm{~F}_{13} \mathrm{~S}\right] /$ water $/ \mathrm{CO}_{2}$ mixtures with different $W_{0}$ values at 350 bar and $45^{\circ} \mathrm{C}$.

Figure 5. SANS profile of $16.7 \mathrm{mM}\left[\mathrm{C}_{6} \mathrm{~F}_{13} \mathrm{mim}\right]\left[\mathrm{C}_{6} \mathrm{~F}_{13} \mathrm{~S}\right] / \mathrm{D}_{2} \mathrm{O} / \mathrm{CO}_{2} \mu \mathrm{E}$ with $W_{0}=20$ at $45^{\circ} \mathrm{C}$ and 350 bar. Solid line is the fitted curve for an oblate ellipsoid form factor. 


\section{References}

(1) Beckman, E. J. Supercritical and Near-Critical $\mathrm{CO}_{2}$ in Green Chemical Synthesis and Processing. J. Supercrit. Fluids. 2004, 28, 121-191.

(2) Goetheer, E. L. V.; Vortaman, M. A. G.; Keurentjes, J. T. F. Opportunities for Process Intensification Using Reverse Micelles in Liquid and Supercritical Carbon Dioxide. Chem. Eng. Sci. 1999, 54, 15891596.

(3) Liu, J.; Cheng, S.; Zhang, J.; Feng, X.; Fu, X.; Han, B. Reverse Micelles in Carbon Dioxide with Ionic-Liquid Domains. Angew. Chem. Int. Ed. 2007, 46, 3313-3315.

(4) Consani, K. A.; Smith, R. D. Observations on the Solubility of Surfactants and Related Molecules in Carbon Dioxide at $50^{\circ} \mathrm{C}$. J. Supercrit. Fluids 1990, 3, 51-65.

(5) Ryoo, W.; Webber, S. E.; Johnston, K. P. Water-in-Carbon Dioxide Microemulsions with Methylated Branched Hydrocarbon Surfactants. Ind. Eng. Chem. Res., 2003, 42, 6348-6358.

(6) Lee, H.; Pack, J W.; Wang, W.; Thurecht, K. J.; Howdle, S. M. Synthesis and Phase Behavior of $\mathrm{CO}_{2}-$ Soluble Hydrocarbon Copolymer: Poly(Vinyl Acetate-alt-Dibutyl Maleate). Macromolecules 2010, 43, $2276-2282$.

(7) Shi, Q.; Jing, L.; Xiong, C.; Liu, C.; Qiao, W. Solubility of Nonionic Hydrocarbon Surfactants with Different Hydrophobic Tails in Supercritical $\mathrm{CO}_{2}$. J. Chem. Eng. Data 2015, 60, 2469-2476.

(8) Li, Q.; Li, T.; Wu, J. Water Solubilization Capacity and Conductance Behaviors of AOT and NaDEHP Systems in the Presence of Additives. Colloids Surf. A 2002, 197, 101-109.

(9) Sagisaka, M.; Yoda, S.; Takebayashi, Y.; Otake, K.; Kitiyanan, B.; Kondo, Y.; Yoshino, N.; Takebayashi, K.; Sakai, H.; Abe, M. Preparation of a W/scCO 2 Microemulsion Using Fluorinated Surfactants. Langmuir 2003, 19, 220-225. 
(10) Lee, C. T., Jr.; Psathas, P. A.; Johnston, K. P.; deGrazia, J.; Randolph, T. W. Water-in-Carbon Dioxide Emulsions: Formation and Stability. Langmuir 1999, 15, 6781-6791.

(11) Johnston, K. P.; Harrison, K. L.; Klarke, M. J.; Howdle, S. M.; Heitz, M. P.; Bright, F. V.; Carlier, C.; Randolph, T. W. Water-in-Carbon Dioxide Microemulsions: A New Environment for Hydrophiles Including Proteins. Science 1996, 271, 624-626.

(12) Zielinski, R. G.; Kline, S. R.; Kaler, E. W.; Rosov, N. A Small-Angle Neutron Scattering Study of Water in Carbon Dioxide Microemulsions. Langmuir 1997, 13, 3934-3937.

(13) Niemeyer, E. D.; Bright, F. V. The pH within PFPE Reverse Micelles Formed in Supercritical $\mathrm{CO}_{2}$. J. Phys. Chem. B 1998, 102, 1474-1478.

(14) Sagisaka, M.; Iwama, S.; Yoshizawa, A.; Mohamed, A.; Cummings S.; Eastoe, J. An Effective and Efficient Surfactant for $\mathrm{CO}_{2}$ Having Only Short Fluorocarbon Chains. Langmuir 2012, 28, 10988-10996.

(15) Sagisaka, M.; Ono, S.; James, C.; Yoshizawa, A.; Mohamed, A.; Guittard, F.; Enick, R. M.; Rogers, S. E.; Czajka, A.; Hill, C.; Eastoe, J. Anisotropic Reversed Micelles with Fluorocarbon-Hydrocarbon Hybrid Surfactants in Supercritical $\mathrm{CO}_{2}$, Colloids Surf. B 2018, 168, 201-210.

(16) Sagisaka, M.; Hino, M.; Sakai, H.; Abe, M.; Yoshizawa, A. Water/Supercritical $\mathrm{CO}_{2} \mathrm{Microemulsions}$ with a Fluorinated Double-tail Surfactant for Syntheses of Semiconductor Ultrafine Particles. J. Jpn. Colour Soc. Mater. 2008, 81, 331-340.

(17) Holmes, J. D.; Steytler, D. C.; Rees, G. D.; Robinson B. H. Bioconversions in a Water-in-CO $\mathrm{CO}_{2}$ Microemulsion. Langmuir 1998, 14, 6371-6376.

(18) Van Roosmalen, M. J. E.; Woerlee, G. F.; Witkamp, G. J.; Surfactants for Particulate Soil Removal in Dry-cleaning with High-pressure Carbon Dioxide. J. Supercrit. Fluids 2004, 30, 97-109. 
(19) Luo, D.; Qiu, T.; Lu, Q. Ultrasound-assisted Extraction of Ginsenosides in Supercritical $\mathrm{CO}_{2}$ Reverse Microemulsions. J. Sci. Food Agric. 2007, 87, 431-436.

(20) Kravetz, L.; Guin, K. F. Effects of Surfactant Structure on Stability of Enzymes Formulated into Laundry Liquids. J. Am. Oil Chem. Soc. 1985, 62, 943-949.

(21) Cooper, A. I.; Londono, J. D.; Wignall, G.; McClain, J. B.; Samulski, E. T.; Lin, J. S.; Dobrynin, A.; Rubinstein1, M.; Burke, A. L. C.; Fréchet, J. M. J.; DeSimone, J. M. Extraction of A Hydrophilic Compound from Water into Liquid $\mathrm{CO}_{2}$ Using Dendritic Surfactants. Nature 1997, 389, 368-371.

(22) Sagisaka, M.; Ogiwara, S.; Ono, S.; James, C.; Yoshizawa, A.; Mohamed, A.; Rogers, S. E.; Heenan, R. K.; Yan, C.; Peach, J. A.; Eastoe, J. A New Class of Amphiphiles Designed for Use in Water-inSupercritical $\mathrm{CO}_{2}$ Microemulsions. Langmuir 2016, 32, 12413-12422.

(23) Yin, H.; Lin, Y.; Huang, J.; Ye, J. Temperature-Induced Vesicle Aggregation in Catanionic Surfactant Systems: The Effects of the Headgroup and Counterion. Langmuir 2007, 23, 4225-4230.

(24) Nakama, Y.; Harusawa, F.; Murotani, I. Cloud Point Phenomena in Mixtures of Anionic and Cationic Surfactants in Aqueous Solution. J. Surfactants Deterg. 1990, 67, 717-721.

(25) Blesic, M.; Swadzba-Kwasny, M.; Seddon, K. R.; Holbrey, J. D.; Rebelo, L. P. N. New Catanionic Surfactants based on 1-Alkyl-3-Methylimidazolium Alkylsulfonates, $\left[\mathrm{C}_{n} \mathrm{H}_{2 n+1} \mathrm{mim}\right]\left[\mathrm{C}_{m} \mathrm{H}_{2 m+1} \mathrm{SO}_{3}\right]$ : Mesomorphism and Aggregation, Phys. Chem. Chem. Phys. 2009, 11, 4260-4268.

(26) Iampietro, D. J.; Brasher, L. L.; Kaler, E. W.; Stradner, A.; Glatter, O. Direct Analysis of SANS and SAXS Measurements of Catanionic Surfactant Mixtures by Fourier Transformation. J. Phys. Chem. B 1998, 102, 3105-3113.

(27) Li, H.; Xin, X.; Kalwarczyk, T.; Kalwarczyk, E.; Niton, P.; Hozyst, R.; Hao, J. Reverse Vesicles from a Salt-Free Catanionic Surfactant System: A Confocal Fluorescence Microscopy Study. Langmuir 2010, 26, 15210-15218. 
(28) Abe'cassis, B.; Testard, F.; Arleth, L.; Hansen, S.; Grillo, I.; Zemb, T. Electrostastic Control of Spontaneous Curvature in Catanionic Reverse Micelles. Langmuir 2007, 23, 9983-9989.

(29) Joensson, B.; Jokela, P.; Khan, A.; Lindman, B.; Sadaghiani, A. Catanionic Surfactants: Phase Behavior and Microemulsions. Langmuir 1991, 7, 889-895.

(30) Abe'cassis, B.; Testard, F.; Arleth, L.; Hansen, S.; Grillo, I.; Zemb, T. Phase Behavior, Topology, and Growth of Neutral Catanionic Reverse Micelles. Langmuir 2006, 22, 8017-8028.

(31) Israelachvili, J. N. Measurements of Hydration Forces Between Macroscopic Surfaces. Chem. Scr. 1985, 25, 7-14.

(32) Nagarajan, R. Molecular Packing Parameter and Surfactant Self-Assembly: The Neglected Role of the Surfactant Tail. Langmuir 2002, 18, 31-38.

(33) Griffin, W.C. Classification of Surface-Active Agents by "HLB”. J. Soc. Cosmet. Chem. 1949, 1, $311-326$.

(34) Griffin, W.C. Calculation of HLB Values of Non-ionic Surfactants. J. Soc. Cosmet. Chem. 1954, 5, 249-256.

(35) Verdia, P.; Gunaratne, H. Q. N.; Goh, T. Y.; Jacquemin J.; Blesic, M. A Class of Efficient ShortChain Fluorinated Catanionic Surfactants. Green Chem. 2016, 18, 1234-1239.

(36) Shi, H.; Wang, X.; Zhao, N.; Qi, L.; Ma, J. Growth Mechanism of Penniform BaWO4 Nanostructures in Catanionic Reverse Micelles Involving Polymers. J. Phys. Chem. B 2006, 110, 748-753.

(37) Shi, H.; Qi, L.; Ma, J.; Wu, N. Architectural Control of Hierarchical Nanobelt Superstructures in Catanionic Reverse Micelles. Adv. Funct. Mater. 2005, 15, 442-450.

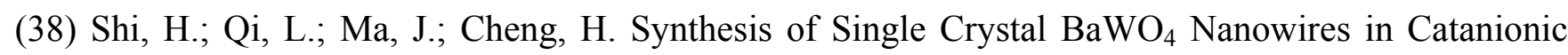
Reverse Micelles. Chem. Commun. 2002, 1704-1705. 
(39) Mahiuddin, S.; Renoncourt, A.; Bauduin, P.; Touraud, D.; Kunz, W. Horseradish Peroxidase Activity in a Reverse Catanionic Microemulsion. Langmuir 2005, 21, 5259-5262.

(40) Biswas, R.; Das, A. R.; Pradhan, T.; Touraud, D.; Kunz, W.; Mahiuddin, S. Spectroscopic Studies of Catanionic Reverse Microemulsion: Correlation with the Superactivity of Horseradish Peroxidase Enzyme in a Restricted Environment. J. Phys. Chem. B 2008, 112, 6620-6628.

(41) Span, R.; Wagner, W. A New Equation of State for Carbon Dioxide Covering the Fluid Region from the Triple-Point Temperature to $1100 \mathrm{~K}$ at Pressures up to $800 \mathrm{MPa}$. J. Phys. Chem. Ref. Data 1996, 25, $1509-1596$.

(42) Kotlarchyk, M.; Chen, S.-H.; Huang, J. S.; Kim, M. W. Structure of Three-Component. Microemulsions in the Critical Region Determined by Small Angle Neutron Scattering Data. Phys. Rev. A 1984, 29, 2054-2069.

(43) Sagisaka, M.; Iwama, S.; Ono, S.; Yoshizawa, A.; Mohamed, A.; Cummings, S.; Yan, C.; James, C.; Rogers, S. E.; Heenan, R. K.; Eastoe, J. Nanostructures in Water-in- $\mathrm{CO}_{2}$ Microemulsions Stabilized by Double-chain Fluorocarbon Solubilizers. Langmuir 2013, 29, 7618-7628.

(44) Smith, G. N.; Grillo, I.; Rogers, S. E.; Eastoe, J. Surfactants with Colloids: Adsorption or Absorption? J. Colloid Interface Sci. 2015, 449, 205-214.

(45) Guinuier, A.; Fournet, G. Small-Angle Scattering of X-Rays, Wiley, New York, 1956.

(46) Kline, S. R. Reduction and Analysis of SANS and USANS Data Using IGOR Pro. J. Appl. Cryst. 2006, 39, 895-900.

(47) Cui, H.; Chen, Z.; Wooleyb, K. L.; Pochan, D. J. Origins of Toroidal Micelle Formation Through Charged Triblock Copolymer Self-Assembly. Soft Matter. 2009, 5, 1269-1278. 
(48) Dhakal, S.; Sureshkumar, R. Topology, Length Scales and Energetics of Surfactant Micelles, J. Chem. Phys. 2015, 143, 024905.

(49) da Rocha, S. R. P.; Harrison, K. L.; Johnston, K.P. Effect of Surfactants on the Interfacial Tension and Emulsion Formation between Water and Carbon Dioxide. Langmuir 1999, 15, 419-428.

(50) Adkins, S. S.; Chen, X.; Chan, I.; Torino, E.; Nguyen, Q. P.; Sanders, A. W.; Johnston, K. P. Morphology and Stability of $\mathrm{CO}_{2}$-in-Water Foams with Nonionic Hydrocarbon Surfactants. Langmuir 2010, 26, 5335-5348.

(51) Mohamed, A.; Sagisaka, M.; Guittard, F.; Cummings, S.; Paul, A.; Rogers, S. E.; Heenan, R. K.; Dyer, R.; Eastoe, J. Low Fluorine Content $\mathrm{CO}_{2}$-philic Surfactants. Langmuir 2011, 27, 10562-10569.

(52) Sarkar, T.; Konar, A.; Sukul, N. C.; Sukul, A.; Chakraborty, I.; Datta, P.; Sutradhar, A. Free Water Molecules and Hydrogen Bonding Form the Basis of Variation in Homeopathic Potencies as Revealed by Vibrational Spectroscopy. Int. J. High Dilution Res. 2015, 14, 8-15.

(53) Sagisaka, M.; Koike, D.; Mashimo, Y.; Yoda, S.; Takebayashi, Y.; Furuya, T.; Yoshizawa, A.; Sakai, H.; Abe, M.; Otake, K. Water/supercritical $\mathrm{CO}_{2}$ Microemulsions with Mixed Surfactant Systems. Langmuir 2008, 24, 10116-10122.

(54) Porod, G. Die Röntgenkleinwinkelstreuung von dichtgepackten kolloiden Systemen. KolloidZeitschrift 1951, 124, 83-114.

(55) Berry, D. H.; Russel, W. B. The Rheology of Dilute Suspensions of Slender Rods in Weak Flows. J. Fluid Mech. 1987, 180, 475-494.

(56) Wierenga, A. M.; Philipse, A. P. Low-Shear Viscosity of Isotropic Dispersions of (Brownian) Rods and Fibres; A Review of Theory and Experiments. Colloids Surf. A 1998, 137, 355-372. 
(57) Simha, R.; The Influence of Brownian Movement on the Viscosity of Solutions. J. Phys. Chem. 1940, $44,25-34$.

(58) Sagisaka, M.; Fujii, T.; Koike, D.; Yoda, S.; Takebayashi, Y.; Furuya, T. Yoshizawa, A.; Sakai, H.; Abe, M.; Otake, K. Surfactant-Mixing Effects on the Interfacial Tension and the Microemulsion Formation in Water/Supercritical $\mathrm{CO}_{2}$ System. Langmuir 2007, 23, 2369-2375. 


\section{Sagisaka, M. ét $t^{23} a_{0}^{6}$}

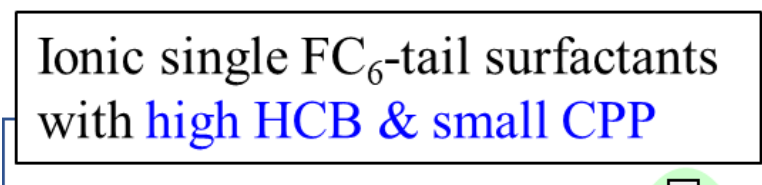

$\underline{\text { In supercritical } \mathrm{CO}_{2}}$ Solubility

Reverse micelle formation Water solubilization No or Very poor In water Surface activity Lowering surface energy Normal

\section{Catanionic surfactant with} low HLB (HCB) \& large CPP

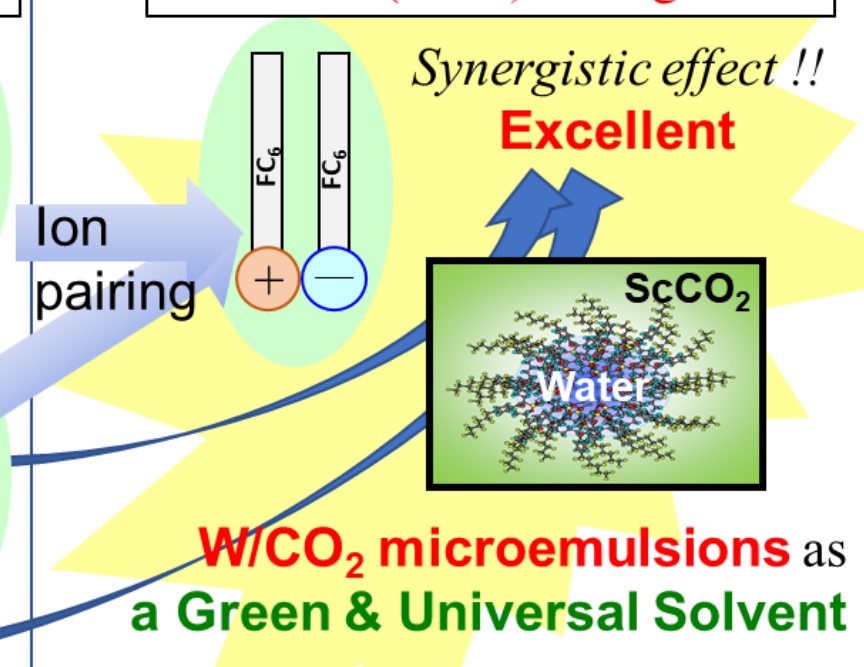




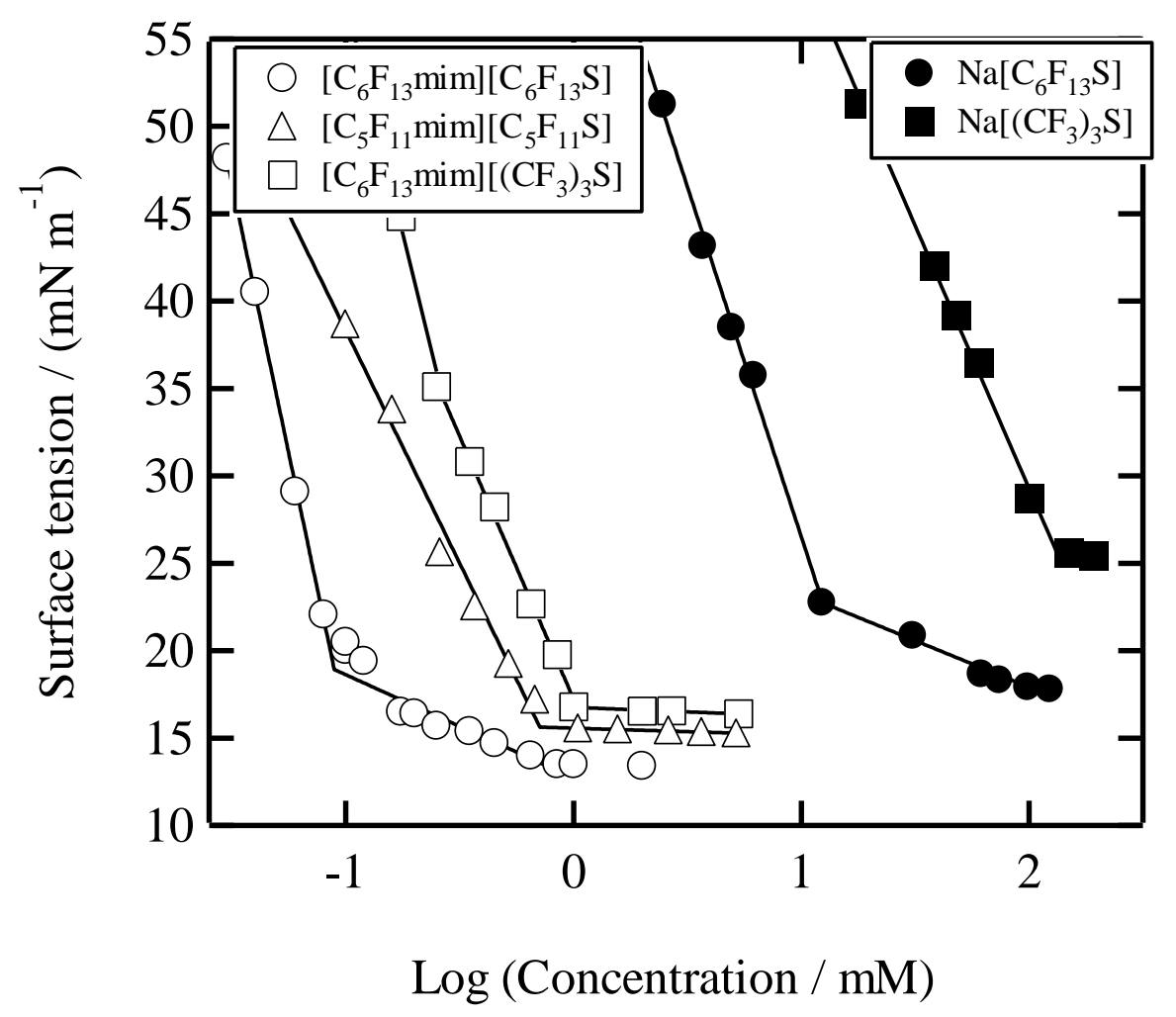

Figure 1 Change in surface tension of aqueous surfactant solutions as a function of surfactant concentration at $23^{\circ} \mathrm{C}$ and 1 bar. Surface tension data for $\left[\mathrm{C}_{6} \mathrm{~F}_{13} \mathrm{mim}\right]\left[\mathrm{C}_{6} \mathrm{~F}_{13} \mathrm{~S}\right]$ and $\left[\mathrm{C}_{6} \mathrm{~F}_{13} \mathrm{mim}\right]\left[\mathrm{C}_{6} \mathrm{~F}_{13} \mathrm{~S}\right]$ are taken from an earlier paper. $^{29}$ 


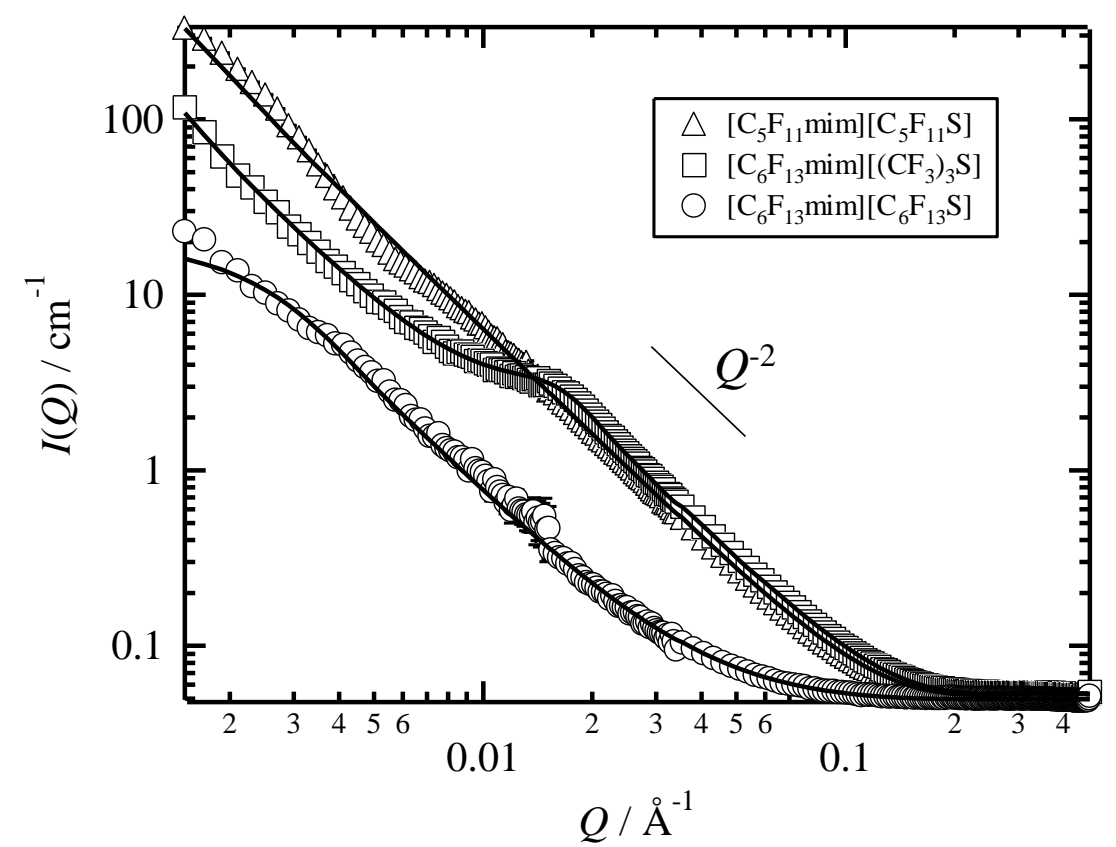

Figure 2 SANS profiles for surfactant $/ \mathrm{D}_{2} \mathrm{O}$ solutions at [surfactant] $=20 \times \mathrm{CMC}, 25^{\circ} \mathrm{C}$ and 1 bar. Solid lines are theoretical curves for core/shell disk form factor model with square well structure factor fitted to the experimental data (symbols). 


\section{Page 3 lof 36
Figure 3}

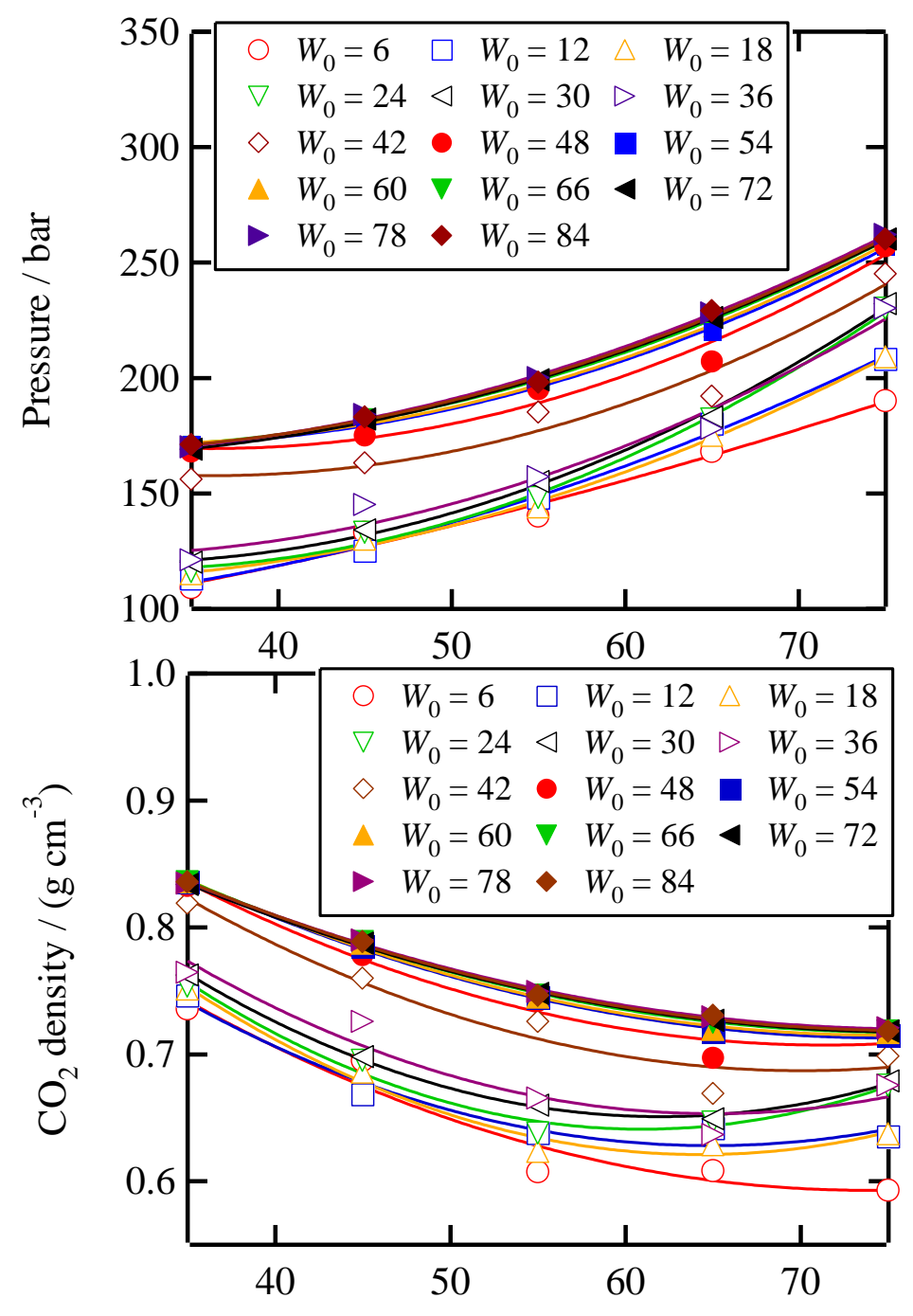

Temperature $/{ }^{\circ} \mathrm{C}$

Figure 3 Changes in $P_{\text {trans }}$ (top) and corresponding $\mathrm{CO}_{2}$ density (bottom) for $\left[\mathrm{C}_{6} \mathrm{~F}_{13} \mathrm{mim}\right]\left[\mathrm{C}_{6} \mathrm{~F}_{13} \mathrm{~S}\right]$ /water/ $/ \mathrm{CO}_{2}$ mixtures with different $W_{0}$ values at [surfactant $] /\left[\mathrm{CO}_{2}\right]=8 \times 10^{-}$ ${ }^{4}$ as a function of temperature. 


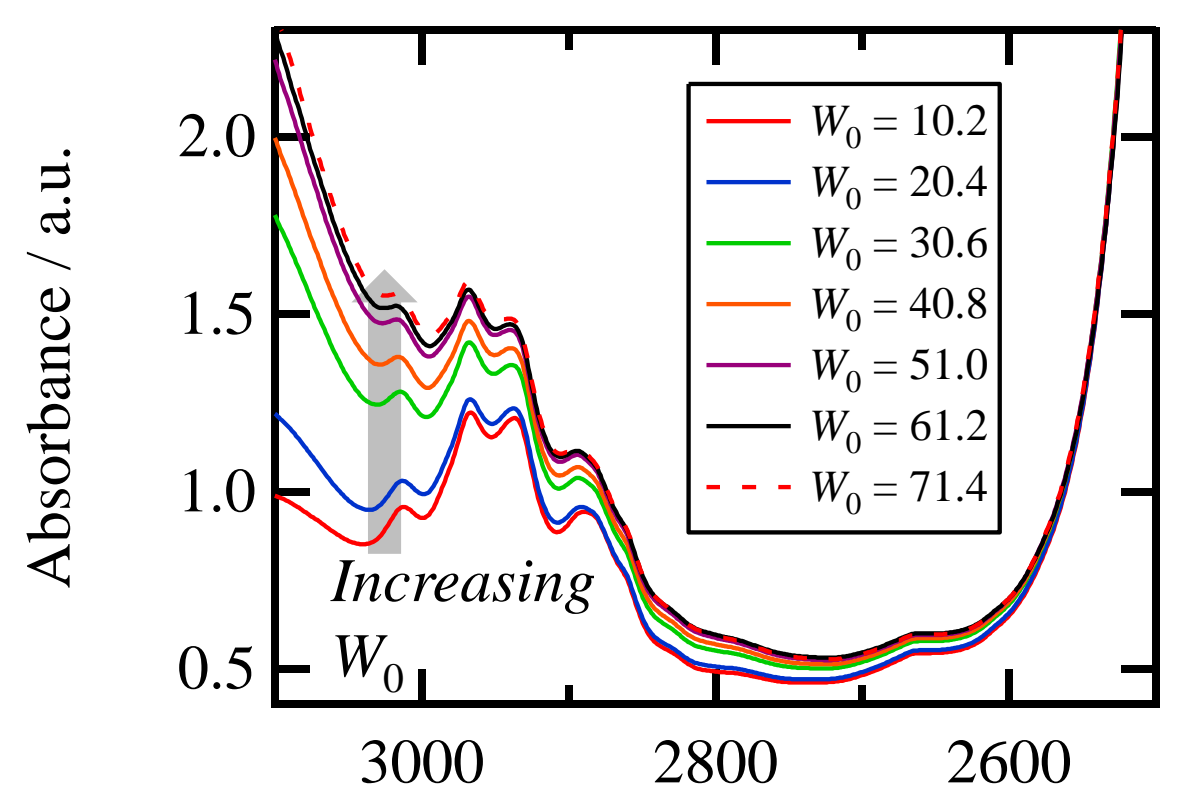

\section{Wavenumber $/ \mathrm{cm}^{-1}$}

Figure 4 FT-IR spectra of $16.7 \mathrm{mM}$ $\left[\mathrm{C}_{6} \mathrm{~F}_{13} \mathrm{mim}\right]\left[\mathrm{C}_{6} \mathrm{~F}_{13} \mathrm{~S}\right] /$ water/ $/ \mathrm{CO}_{2}$ mixtures with different $W_{0}$ values at 350 bar and $45^{\circ} \mathrm{C}$. 


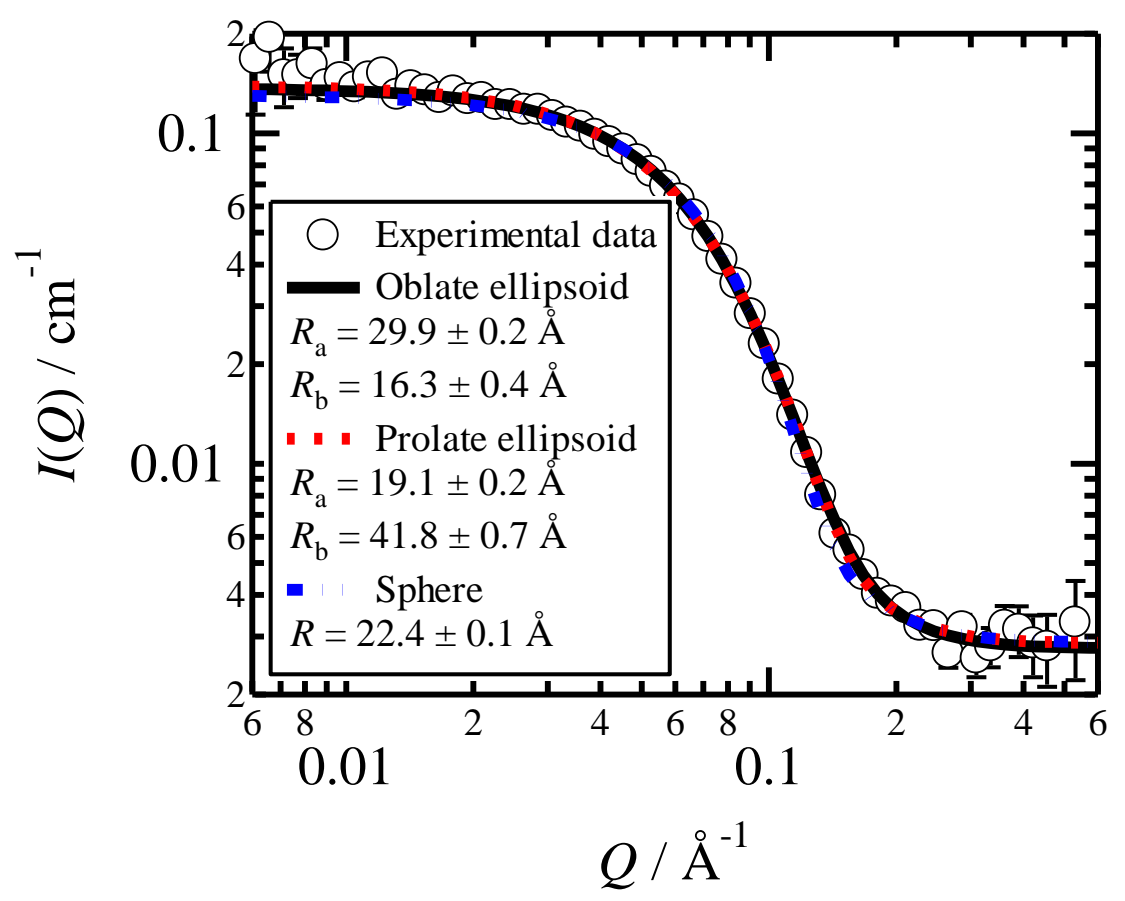

Figure 5 SANS profile of $16.7 \mathrm{mM}$ $\left[\mathrm{C}_{6} \mathrm{~F}_{13} \mathrm{mim}\right]\left[\mathrm{C}_{6} \mathrm{~F}_{13} \mathrm{~S}\right] / \mathrm{D}_{2} \mathrm{O} / \mathrm{CO}_{2} \mu \mathrm{E}$ with $W_{0}=20$ at $45{ }^{\circ} \mathrm{C}$ and 350 bar. Solid line is the fitted curve for an oblate ellipsoid form factor. 
Table 1 Chemical structures of surfactant ions.

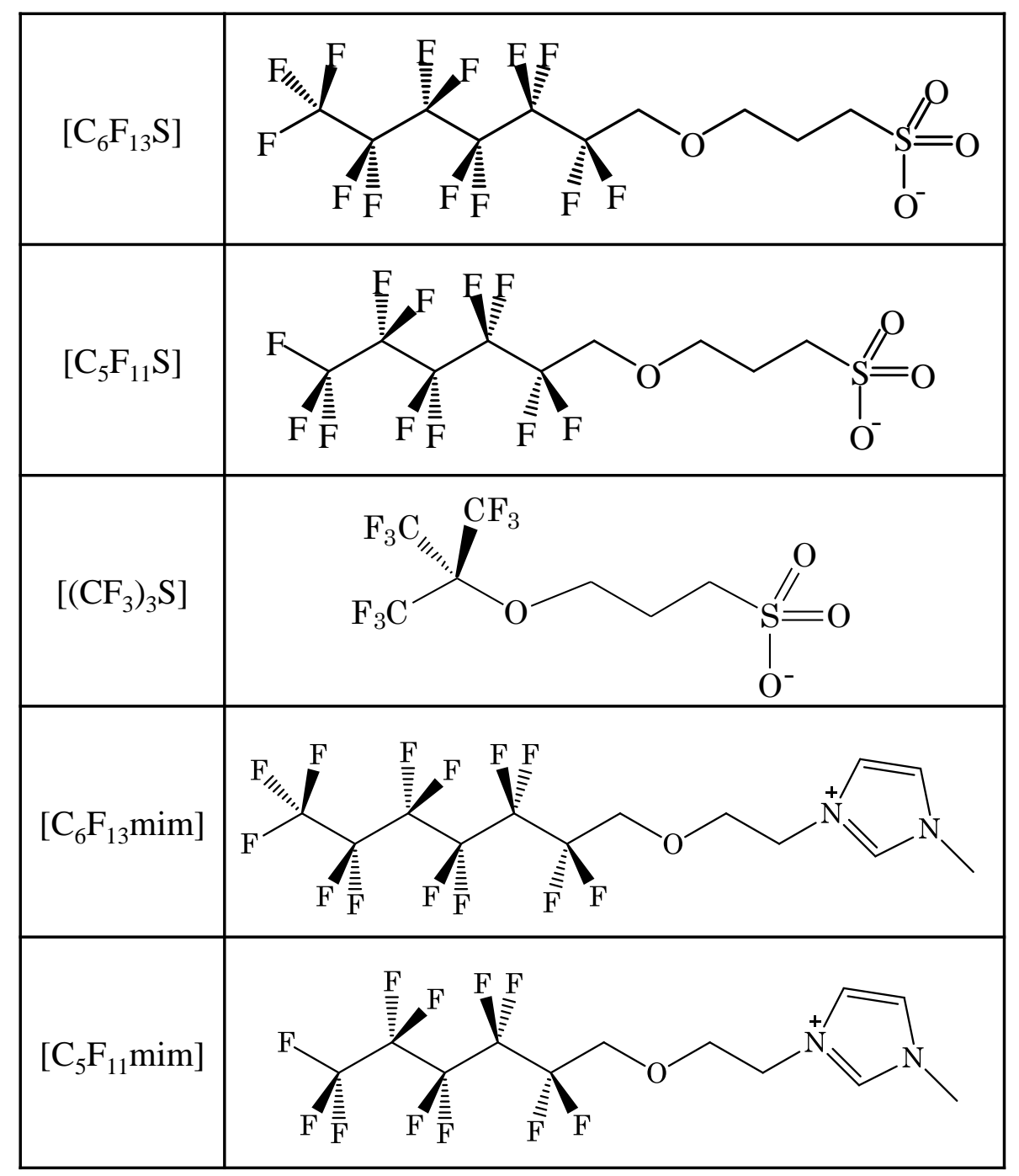


Table 2 Properties of aqueous surfactant solutions at $25^{\circ} \mathrm{C}$ and 1 bar

\begin{tabular}{ccc}
\hline Surfactant & $\mathrm{CMC} / \mathrm{mM}$ & $\gamma_{\mathrm{CMC}} /\left(\mathrm{mN} \mathrm{m}^{-1}\right)$ \\
\hline$\left[\mathrm{C}_{6} \mathrm{~F}_{13} \operatorname{mim}\right]\left[\mathrm{C}_{6} \mathrm{~F}_{13} \mathrm{~S}\right]$ & $0.8-1.1 \times 10^{-1}$ & 13.5 \\
{$\left[\mathrm{C}_{5} \mathrm{~F}_{11} \operatorname{mim}\right]\left[\mathrm{C}_{5} \mathrm{~F}_{11} \mathrm{~S}\right]$} & $7.0 \times 10^{-1}$ & 15.3 \\
{$\left[\mathrm{C}_{6} \mathrm{~F}_{13} \mathrm{mim}\right]\left[\left(\mathrm{CF}_{3}\right)_{3} \mathrm{~S}\right]$} & 1.0 & 16.8 \\
$\mathrm{Na}\left[\mathrm{C}_{6} \mathrm{~F}_{13} \mathrm{~S}\right]$ & $1.3 \times 10^{1}$ & 22.6 \\
$\mathrm{Na}\left[\left(\mathrm{CF}_{3}\right)_{3} \mathrm{~S}\right]$ & $1.3 \times 10^{2}$ & 25.7 \\
\hline
\end{tabular}

$\mathrm{CMC}$ and $\gamma_{\mathrm{CMC}}$ data for $\left[\mathrm{C}_{6} \mathrm{~F}_{13} \mathrm{mim}\right]\left[\mathrm{C}_{6} \mathrm{~F}_{13} \mathrm{~S}\right]$ and $\left[\mathrm{C}_{6} \mathrm{~F}_{13} \mathrm{mim}\right]\left[\mathrm{C}_{6} \mathrm{~F}_{13} \mathrm{~S}\right]$ are taken from the earlier paper $^{29}$ 


\section{Sagisaka}

Table 3 FC-core radius $\left(R_{\mathrm{f}-\mathrm{Cdisk}}\right)$ and thickness $\left(t_{\mathrm{f}-\mathrm{Cdisk}}\right)$, HC-shell thickness $\left(t_{\mathrm{f}-S d i s k}\right)$, aspect ratio, well depth and width for catanionic surfactant disk-like micelles in $\mathrm{D}_{2} \mathrm{O}$ at [Surfactant] $=20 \times \mathrm{CMC}, 25^{\circ} \mathrm{C}$ and 1 bar, obtained by SANS data analysis with theoretical curves for core/shell disk form factor model with square well structure factor, and cloud temperatures.

\begin{tabular}{cccccccc}
\hline \multirow{2}{*}{ Surfactant } & $\begin{array}{c}R_{\mathrm{f}-\text { Cdisk }} \\
/ \AA\end{array}$ & $\begin{array}{c}t_{\mathrm{f}-\text {-Cdisk }} \\
\mathrm{A} \AA\end{array}$ & $\begin{array}{c}\mathrm{t}_{\mathrm{f}-\text { Shell }} / \AA \\
/ \AA\end{array}$ & $\begin{array}{c}\text { Aspect } \\
\text { ratio }\end{array}$ & $\begin{array}{c}\text { Well } \\
\text { depth } / \mathrm{kT}\end{array}$ & $\begin{array}{c}\text { Well } \\
\text { width }\end{array}$ & $\begin{array}{c}\text { Cloud } \\
\text { temp } /{ }^{\circ} \mathrm{C}\end{array}$ \\
\hline$\left[\mathrm{C}_{5} \mathrm{~F}_{11} \operatorname{mim}\right]\left[\mathrm{C}_{5} \mathrm{~F}_{11} \mathrm{~S}\right]$ & 2180 & 12.0 & 5.0 & 0.003 & 1.5 & 1.0 & $<0$ \\
{$\left[\mathrm{C}_{6} \mathrm{~F}_{13} \operatorname{mim}\right]\left[\mathrm{C}_{6} \mathrm{~F}_{13} \mathrm{~S}\right]$} & 636 & 13.3 & 4.7 & 0.010 & 1.5 & 1.0 & - \\
{$\left[\mathrm{C}_{6} \mathrm{~F}_{13} \operatorname{mim}\right]\left[\left(\mathrm{CF}_{3}\right)_{3} \mathrm{~S}\right]$} & 130 & 11.5 & 5.0 & 0.045 & 0.3 & 2.8 & 29.8 \\
\hline
\end{tabular}

